\title{
Eriugenism in Berthold of Moosburg's Expositio super Elementationem theologicam Procli
}

\author{
Evan King \\ University of King's College, Halifax
}

The importance of sources transmitting the thought of John Scotus Eriugena for the Expositio super Elementationem theologicam Procli written by Berthold of Moosburg O.P. (sometime between 1327 and 1361) has been acknowledged among Berthold's contemporary readers at least since 1974. In that year, Loris Sturlese and Paolo Lucentini published, respectively, critical editions of Berthold's Expositio (Propositions 184-211) and the 12th-century Clavis physicae of Honorius Augustodunensis in the series Temi e testi. ${ }^{1}$ Eugenio Massa, as editor of the series, highlights the importance of their concurrent publication and offers insightful suggestions for situating Berthold within the broader currents of medieval Eriugenism, especially in view of the theory of deification expounded in the Expositio. ${ }^{2}$

The name of Berthold of Moosburg has remained almost entirely absent from surveys of the subsequent reception of Eriugena's thought. ${ }^{3}$ This is due perhaps to the provisional nature of judgements like Massa's, which relied on only a partial edition of the Expositio. As of 2014, the eight-volume edition of the commentary is available in the Corpus Philosophorum Teutonicorum Medii Aevi. ${ }^{4}$ In 2013, Ezequiel Ludueña demonstrated the character and the extent of Berthold's debt to Eriugenian sources in his doctoral dissertation for the University of Buenos Aires. ${ }^{5}$ It is fitting that the first monograph-length study to

1 Berthold von Moosburg 1974 = De animabus; Honorius Augustodunensis 1974 = Clavis. Chapters $316-529$ from the Clavis are cited according to the critical edition of Pasquale Arfé: Honorius Augustodunensis 2012 = Clavis. Citations of the Expositio super Elementationem theologicam Procli refer to the critical edition: Berthold von Moosburg 1984-2014 = Expositio. References indicate proposition number and section (e.g., 2B), followed by page and line number. Citations of the Prologus (Prologus) refer to Berthold von Moosburg 1984.

2 De animabus, p. v-x.

3 E.g. Beierwaltes 1987.

4 Berthold von Moosburg 1984-2014. Citations refer to a section of the Expositio, followed by page and line number.

5 Ludueña 2013a. See also Ludueña 2013b and 2015. 
focus on Berthold is devoted to his indirect but substantial debt to Eriugena's thought. Any historical analysis of the overall spirit and doctrine of the Expositio cannot afford to overlook its fundamental role in shaping the character of the commentary. The following essay consolidates and builds upon this line of interpretation. Here I cannot discuss the important themes first outlined by Eugenio Massa which help us to situate the Expositio in its cultural context. ${ }^{6}$ Similarly, on the topic of Berthold's reception of the Eriugenian doctrine of the primordial causes (causae primordiales), I refer the reader to the work of Ezequiel Ludueña. ${ }^{7}$ I focus instead on two interrelated aspects of Berthold's reception of Eriugena. First, I provide a synthetic account of the Eriugenian sources in Berthold which is sensitive to his attitude toward these texts as authorities. Then I present the centrality of the Clavis in Berthold's effort to provide an authoritative Christian equivalent to one of the most challenging doctrines in the Elementatio theologica, on the soul's permanent "vehicle" (susceptaculum). From this it should become clear that Berthold's Expositio must be regarded as the most extensive medieval reception of Eriugena's thought known to date, after the Clavis physicae of Honorius Augustodunensis.

\section{1 \\ Sources}

By "Eriugenism", I mean the transmission and modification of the writings, characteristic vocabulary and doctrines of John Scotus Eriugena. From a relatively early date, this textual transmission divided into several, occasionally intertwining branches. ${ }^{8}$ The specific meaning of Eriugenism must be determined in each instance both with reference to the works at an author's disposal and the frequently incorrect attributions which these works bore. Both factors play an important role in Berthold of Moosburg's reception of Eriugena, as they

6 The connections between theory of deification adopted from the Clavis into the Expositio and the controversies surrounding the reception of Eriugena from the early $13^{\text {th }}$ century and Amalric of Bene to Nicholas of Cusa in the mid-15th century cannot be taken up here. The results of my own research into the reception of the Expositio corroborate Massa's suggestions, and will be published in my forthcoming monograph on Berthold of Moosburg. See also Ludueña 2010.

7 Ludueña demonstrates how Berthold understood the causality of the gods in Proclus as equivalent to the essential causality of the primordial causes, and he traces the background to this reception in Berthold's Dominican predecessors, Dietrich of Freiberg, Ulrich of Strassburg and Albert the Great. Looking forward from Eriugena, Christophe Erismann calls the Irishman "the father of causa essentialis". See Erismann 2002, p. 198.

8 On their manuscript traditions, see Mainoldi 2005. 
can be shown to have influenced fundamental features of his project's doxographical and philosophical assumptions.

Aside from providing a few basic orientations, there is no need to rehearse the complexities of the history of Eriugenism up to the 12th century, which have been well-documented by Paolo Lucentini. ${ }^{9}$ Only those branches which have an impact on Berthold's thought must be considered here: the principal conduit of Eriugenism in this case is the Clavis physicae of Honorius Augustodunensis, the great paraphrase-adaptation of Eriugena's Periphyseon. Berthold attributes the work to a Theodorus, abbot of Constantinople. In second place are the scholia accompanying Eriugena's translation of Dionysius which, by the mid-13th century, had expanded to include excerpts from the Periphyseon and were indiscriminately attributed to Maximus (the famous example of this is MS BnF, lat. 17341, the Parisian Corpus Dionysiacum studied by H.-F. Dondaine). ${ }^{10}$ Then there is the Liber de causis primis et secundis et fluxu quod ad ea consequitur, which Berthold calls De causa causarum and attributes to Al-Fārābī. Finally, there is a limited influence of Eriugena's Homily on the Gospel of John, commonly circulated with an attribution to Origen.11

Unlike most of the authors influenced by Eriugena who have been studied by Paolo Lucentini, Édouard Jeauneau and John Marenbon, ${ }^{12}$ the notion of a specifically "Eriugenian" doctrine is, with one exception (i.e. the doctrine of theophanies), unknown to Berthold: the name of John Scotus appears only in Berthold's list of his sources of Doctors of the Church (and only in the Oxford, not the Vatican manuscript) and once in the body of the Expositio, in a quotation taken from Albert the Great's Summa theologiae on God's condescension to the created intellect in veils and theophanies. ${ }^{13}$ It is important to bear in mind that, while from our perspective a certain group of treatises transmitting passages from Eriugena's works have substantially shaped Berthold's thought, Berthold's outlook is fundamentally different. As will be clear, he reads these works as belonging within a tradition of interpreting Dionysius.

$9 \quad$ Lucentini 1980, p. 5-75.

10 Dondaine 1953, p. 69-71, 88-89, 101, 118.

11 See Jeauneau's introduction to his edition of the Homily, p. 53-54.

12 Marenbon 1981; Jeauneau 1987.

13 Prologus 16, p. 25, l. 665-671; cf. Albertus Magnus, Summa theologiae Ia, tr. 3, q. 13, c. 1, p. 40, l. $3^{-11 .}$ 


\subsection{Theodorus, abbas Constantinopolitanus}

Loris Sturlese has shown that Berthold's attribution of Honorius's Clavis physicae to Theodorus, abbot of Constantinople, follows from his use of a specific manuscript (Ms Paris, BnF, lat. 6734) in which he left marginal crosses. These have been documented by Sturlese, and are arranged in a table, below. ${ }^{14}$ Eventually the same manuscript would be read by Nicholas Cusanus, who also left marginal markings as well as notabilia. ${ }^{15}$

One of the manuscript's frontispieces depicts a dialogue between an elder Abbot Theodore of the Greeks and a younger student, John the monk of the Latins $\left(\mathrm{f} .3^{\mathrm{r}}\right)$. Marie-Thérèse d'Alverny has studied this frontispiece along with the other images adorning the initial folios of the 12th-century manuscript. ${ }^{16}$ On the basis of iconographic similarities with other works produced in the scriptorium of Prüfening, D' Alverny traces its origins back to this abbey on the outskirts of Regensburg, where Honorius himself may have resided. ${ }^{17}$ As Loris Sturlese notes, D' Alverny's hypothesis about the Regensburg origins of MS Paris, BnF, lat. 6734, offers a possible explanation of how Berthold could have studied the text so closely, given than he appears as a lector of the Dominican studium in Regensburg in 1327.18

The original intention of the scriptores, D' Alverny suggests, may have been to depict how Eriugena acquired his knowledge of Greek literature, perhaps looking to the historical figure of Theodore of Tarsus, who is presented by chroniclers as a philosopher learned in Greek and Latin letters. Thus John the monk, translator of Dionysius the Areopagite, Gregory of Nyssa and Maximus the Confessor, is placed here in a lineage with Theodore, under whom the Cathedral school of Canterbury flourished, and who brought Greek learning to the Latin world.

However, one cannot derive the epithet added by Berthold, Constantinopolitanus, from the image, which only identifies Theodore as a "Greek abbot". He may simply embellish this detail or, perhaps, he also looks to an historical figure, though not to Theodore of Tarsus, since Bede and the chroniclers never associate him with Constantinople. A more likely candidate is Theodore Studite (759-826). Anastasius Bibliothecarius, the translator and compiler of scholia

\footnotetext{
14 De animabus, p. xliii-xlv. The manuscript may be viewed on-line: http://gallica.bnf.fr/ ark:/12148/btvib9o665224 (accessed 20 April 2017). On the history of the manuscript, see Lucentini, Clavis, p. ix-xv.

15 Lucentini 1980, p. 77-109.

16 D' Alverny 1953.

17 D' Alverny 1953, p. 34, n. 1 and 36, n. 1.

18 De animabus, p. xvii.
} 
for Eriugena's translation of Dionysius, also translated two Byzantine chronicles of Theophanes, as well as Theodore Studite's sermon on St. Bartholomew, in 869-87o. Here he is described as a venerable abbot of Constantinople. Anastasius's dedicatory letter to his translation of Theodore's sermon reads:

Theodorus namque quidam sacerdos apud Constantinopolitanum urbem fuit temporibus Adriani et Leonis Romanorum pontificum, vir satis mirabilis, qui cum non solum scientia sed signis polleret, duum imperialium et insignium monasteriorum, Studii scilicet et Saccudiorum, constitutus est abbas. Qui cum semper in apostolicae sedis communione persisteret, et hereticorum nenias et imperatorum vesaniam, etiam tormentis affectus, mentis virtute repressit. ${ }^{19}$

Only one manuscript of this text survives. ${ }^{20}$ Berthold may have received similar information through another intermediary. In any case, by the 16th century, Theodore Studite would be included in the Martyrologium Romanum, which reads for his feast day on 11 November:

Constantinopoli sancti Theodori, Abbatis Studitae, qui, pro fide catholica adversus Iconoclastas strenue pugnans, factus est in universa Ecclesia catholica celebris.

In 1691, Thomas Gale refers to a manuscript as Disputatio quaedam cum Theodoro Studita, which he argues should not be attributed to Eriugena, since Gale realises that St. Theodore the Studite lived before John Scotus, "and so it seems that this celebrated disputation belongs to the cult of images".21 This remark almost certainly indicates an association of this frontispiece with St. Theodore.

Whether or not this is the specific figure Berthold has in mind, the intellectual consequences of granting this authority to the Clavis are significant. In light of what follows, one could say that the 12th-century frontispiece begins a gesture which, in Berthold's work, finds its completion. ${ }^{22}$ In this manuscript of the Clavis, Eriugena has become transparent to the wisdom of the Greeks, which he disseminated as translator and reinvented in his Periphyseon.

19 Pratsch 1998, p. 312-313.

20 Originally made near Laon before 895 , now MS BNF lat. 5095, f. $27^{\mathrm{v}}-5^{8 \mathrm{v}}$ (see Allen-Neil 2002, p. 32).

21 Patrologia latina CXXII, p. 96 and 99. Lehmann 1917, p. 113-115, links this remark with the Clavis; Lucentini, Clavis, p. ix, n. 2. 
In the Expositio, Berthold cites passages from ninety-three different chapters of the Clavis for a total of one-hundred and thirty-two citations. ${ }^{23}$ In lengthier citations, he identifies the speaker as Magister or Discipulus, but does not associate the former with Theodore and the latter with John. As is his custom with older sources, Berthold's citations of the Clavis are almost always explicit; however, as we shall see, he also copies the text without attribution for teachings from older sources like Dionysius the Areopagite or Maximus. ${ }^{24}$ In light of the distribution of citations in the Expositio, one notices that Berthold looks to the Clavis physicae primarily on two essential points. The most extensive and sustained concentration of Clavis citations (twenty-five) falls between Propositions 120-129, on the gods and their providence. The most intensive concentration is found in Propositions 196 (seven) and 210 (twelve), with other citations clustered nearby, which are the central passages on the doctrine of the soul's imperishable, immaterial body (susceptaculum, óx $\eta \mu \alpha$ ). In comparison to the doctrine of primordial causes, the presence of Eriugenism is more volatile here, since Proclus must be corrected more forcefully to be brought into accord with the Christian and pagan Platonic consensus which it is the aim of the Expositio to elucidate.

The marginal crosses and notabilia written by Berthold in the margins of his Clavis manuscript are arranged in the following table, providing references to the modern critical editions and to the citations of these passages from the Clavis in the Expositio. ${ }^{25}$

23 Chapters are counted according to the modern editions of Lucentini and Arfé. The subject headings in the margins of the manuscript used by Berthold do not always correspond to this enumeration. Berthold refers to the text as a continuous piece. Therefore, citations have been counted when Berthold himself makes distinct references to the text. He usually presents clusters of citations in relation to one another (e.g., Expositio, 2A: parum supra, aliqualiter infra), even passages which are far apart (e.g., bene infra, in Expositio, 196F, leaps from chapters 105 to 272; but in Expositio, 3A, only from 137 to 142). Sometimes he refers both to the approximate location in the manuscript (circa medium) and gives a vague reference to the subject heading in the margin (e.g., Expositio, 8oG).

24 Cf. Expositio, $119 \mathrm{E}$.

25 A conferre indicates that a citation occurs in the Expositio which is closely related to, but not identical with, the text marked in the manuscript. This table omits the corrections to the text and the transliterations written in the margins by Berthold, listed in De animabus, p. xliv-xlv. 


\section{Clavis physicae Clavis physicae Ms Paris, BnF, lat. 6734 \\ Berthold of Moosburg, Expositio}
f. $7^{\mathrm{v}}$
13 (p. 10, l. 4-7)
f. $9^{\mathrm{r}}$
16 (p. 12, l. 6-10)
f. $16^{\mathrm{v}}$
43 (p. 27, l. 14-17)
f. $31^{\mathrm{r}}$
76 (p. 54, l. 8)
129A, 21OE, 21OI
f. $35^{\mathrm{r}}$
83 (p. 6o, l. 18)
f. $35^{\mathrm{v}}$
86 (p. 61, l. 1-2)
Cf. Prol. 4
f. $38^{\mathrm{v}}$
91 (p. 66, l. 30-31)
$126 \mathrm{~B}$
f. $38^{\mathrm{v}}$
91 (p. 66, l. 39-4o)
$126 \mathrm{~B}$
f. $39^{\mathrm{v}}$
94 (p. 68, l. 21-22)
$196 \mathrm{~F}$
f. $42^{\mathrm{v}}$
102 (p. 74, l. 28-29)
$196 \mathrm{~F}$
f. $42^{\mathrm{v}}-43^{\mathrm{r}}$
102 (p. 74, l. 37)
$196 \mathrm{~F}$
f. $43^{\mathrm{r}}$
103 (p. 75, l. 10-11)
$196 \mathrm{~F}$
f. $43^{\mathrm{v}}$
105 (p. 76, l. 4-6)
$196 \mathrm{~F}$
f. $78^{\mathrm{r}}$
170 (p. 135, l. 9-10)
Cf. 14OD
f. $97^{\mathrm{v}}$
f. $106^{v}$
221 (p. 172, l. 2-3)
242 (p. 191, l. 8-9)
$-$
f. $120^{\mathrm{v}}$
272 (p. 219, l. 2-4)
196F, 21OE
["de corpore spirituali"]
f. $121^{\mathrm{r}}$
f. $140^{\mathrm{v}}$
273 (p. 221, l. 18-19)
Cf. 196F, 210C, 210M
f. $158^{\mathrm{v}}$
308 (p. 261, l. 17-18)
360 (p. 94, l. 1000-1002) $\quad 18 \mathrm{C}$
f. $159^{\mathrm{r}}$
361 (p. 95, l. 1039-1040) $\quad$ 18C
f. $200^{\mathrm{v}}$
["catholica elementa"]
440 (p. 168, l. 3507-3509) -
f. $200^{\mathrm{v}}$
f. $201^{\mathrm{v}}$
["I ${ }^{a}$ materies"]
f. $202^{\mathrm{r}}$
[ "I $I{ }^{a}$ materies"]
441 (p. 168, l. 3522-3528) -
442 (p. 170, l. 3591-3598) -
f. $208^{\mathrm{v}}$
f. $212^{\mathrm{r}}$
f. $228^{\mathrm{v}}$
442 (p. 17o, l. 3599-36o1) -
f. $229^{\mathrm{v}}$
451 (p. 181, l. 3991-3993) -
459 (p. 188, l. 4206-4207) -
486 (p. 215, l. 5162-5163) -
487 (p. 216, 1. 5223-5224) - 
Particular themes in the Clavis seem to have caught Berthold's attention: the theory of the invisible "universal" elements mediating between the fully spiritual and the fully corporeal (Clavis 43, 76, 83, 221, 273, 440, 442); the doctrine of the spiritual body (Clavis 102, 103, 105, 272, 273, 486, 487); the primordial causes (Clavis 16, 86, 91, 170); the return of all things (Clavis 308, 441, 459); the human as imago Dei (Clavis 94, 242); the goodness of creation and its substantiality (Clavis $361,451)$; theophany (Clavis 13). Overall, it seems he is most interested in passages dealing with the mediation between the visible, corporeal and invisible, spiritual orders (invisible elements and spiritual bodies), and the origin and destiny of all things in the primordial causes. Just like his master, Dietrich of Freiberg, Berthold's metaphysics of intellect and his natural philosophy form an integral whole. ${ }^{26}$ It may be that Berthold found in the Clavis crucial authority for outlining the relationship between these two sides of his philosophical work.

\subsection{Maximus, Commentator Dionysii}

After Theodore, the most important channel of Eriugenian influence comes to Berthold under the name of Maximus. By the middle of the 13th century, excerpts of the Periphyseon appear alongside Eriugena's second redaction of his translation of the Corpus Dionysiacum, known today as the Versio Dionysii, in addition to the scholia inserted by Anastasius Bibliothecarius (from John of Scythopolis and Maximus the Confessor) which, by that time, had lost Anastasius's marginal crosses indicating the attribution of each scholium. ${ }^{27}$ Berthold cites twelve different "commentaries" on Dionysius a total of sixteen times (see table, below). Of these twelve, eight come from the Periphyseon and are therefore Eriugenian. Berthold attributes these either to Maximus, to an anonymous Commentator or to an Expositor. Identical citations with alternating attributions indicate that he believes that Maximus is author of all of these remarks.

Each of Berthold's citations of the eight Eriugenian commentaries has an indirect source: seven are found in nearly identical forms in Albert the Great's Summa theologiae and Commentary on the Divine Names, and one is from the De summo bono of Ulrich of Strassburg. ${ }^{28}$ Berthold embellishes Ulrich's attribution to Maximus by adding monachus — an epithet which he finds in the Clavis physicae. ${ }^{29}$ As for the four non-Eriugenian scholia, two also come from Albert:

\footnotetext{
26 Cf. Pagnoni-Sturlese 1984; Sturlese 1985.

27 Dondaine 1953; Suchla 1980.

28 Berthold cites a scholium on the primordial causes once as it is found in the Summa theologiae, at Prologus 4, and later as found in Albert the Great, Super Dion. DDN, at 21F.

29 Clavis 3, p. 4, 1. 7-10: [...] de greca summi theologi Dionisius Ariopagita, Gregorius Nazan-
} 
one is a short phrase copied from his Super Dionysium De divinis nominibus $(D D N)$ on the superiority of the intelligible over the intellectual (163D); and one is from Albert's Super Dionysium De caelesti hierarchia $(D C H)$, on the doctrine of analogy, to which Berthold adds an explicit attribution to Maximus (110D). The remaining two are not found in Albert or Ulrich: one derives from Thomas Gallus's Explanatio of Dionysius, which Berthold finds in the Sapientiale of Thomas of York and attributes once to the Expositor (23I) and once to Maximus (14E); and one brief comment from an Expositor on Dionysius, De divinis nominibus 13 concerning the participation of all things in unity $(5 \mathrm{E})$. I have not found its source, but I suspect that it also comes from Thomas of York.

All sixteen occurrences of the twelve citations attributed by Berthold to Maximus, the Commentator or the Expositor are arranged in the following table. Passages from the Expositio are paired where a second citation repeats only a portion of an earlier one.

\begin{tabular}{|c|c|c|}
\hline $\begin{array}{l}\text { Berthold } \\
\text { Expositio }\end{array}$ & Direct source & Periphyseon \\
\hline [E1] Prol. 4 \& Prol. 9 & $\begin{array}{l}\text { Albert the Great, Summa theologiae, Ia, tr. 13, } \\
\text { q. } 55, \text { m.2, a.1, p. } 559 \text { b }-56 \text { oa }\end{array}$ & II.529AB \\
\hline $5^{\mathrm{E}}$ & Non inveni & $\mathrm{n} / \mathrm{a}$ \\
\hline$[\mathrm{E} 2] 7 \mathrm{~B}$ & $\begin{array}{l}\text { Albert the Great, Summa theologiae, Ia, tr. } 6 \text {, } \\
\text { q. } 26 \text {, c. } 1, \text { a. } 2 \text {, part. 1, p. } 173, \text { l. } 5^{1-59}\end{array}$ & II. 58 oCD \\
\hline $\begin{array}{l}{[\mathrm{E} 3] 14 \mathrm{E}, 17 \mathrm{D} \& 23 \mathrm{I}} \\
(\text { p. } 121,1.327-328)\end{array}$ & $\begin{array}{l}\text { Clavis physicae, c. } 65, \text { p. } 45, \text { l. } 4-6 \text {; } \\
\text { cf. Albert, Super } D D N, 9.21, \text { p. } 39 \text { o, l. 12-15 }\end{array}$ & $\mathrm{I} .515 \mathrm{C}$ \\
\hline$[\mathrm{E} 4] 16 \mathrm{~A}$ & $\begin{array}{l}\text { Clavis physicae, c. } 65 \text {, p. } 45 \text {, l. } 4 \text {; c. } 67, \text { p. } 46 \text {, } \\
\text { l. } 4-8 \text {; cf. Albert, Summa theologiae, Ia, tr. } 6 \text {, } \\
\text { q. } 26 \text {, c. } 1, \text { a. } 2 \text {, part. } 4 \text {, p. } 179,1.78-81\end{array}$ & I.515C, I.519B \\
\hline $\begin{array}{l}\text { 16B } \\
\& 23 \mathrm{I}(122,372-374)\end{array}$ & $\begin{array}{l}\text { Thomas of York, Sapientiale }{\mathrm{I} .177^{30}} \\
\text { cf. Thomas Gallus, Explanatio super DDN, c. } 4 \text {, } \\
\text { p. } 1646-1654\end{array}$ & $\mathrm{n} / \mathrm{a}$ \\
\hline$[\mathrm{E} 5] 16 \mathrm{~B}$ & Clavis physicae, c. 67, p. $46,1.8-47$, l. 16 & I. $519 \mathrm{C}-52 \mathrm{OA}$ \\
\hline$[\mathrm{E} 6] 21 \mathrm{~F}$ & $\begin{array}{l}\text { Albert the Great, Super } D D N, 5.24, \text { p. } 316, \text { l. } 70- \\
\text { p. } 317,1.7\end{array}$ & II.529AB \\
\hline
\end{tabular}

zenus et Gregorius Niseus eiusque frater Basilius, Iohannes Crisostomus nec non Maximus monachus precipuus philosophus et episcopus auctoritatem prebeant. 
(cont.)

\begin{tabular}{|c|c|c|}
\hline $\begin{array}{l}\text { Berthold } \\
\text { Expositio }\end{array}$ & Direct source & Periphyseon \\
\hline [E7] 64C & $\begin{array}{l}\text { Albert the Great, Summa theologiae Ia, tr. } 13 \text {, } \\
\text { q. } 55, \text { m. } 2 \text {, a. } 2 \text {, s.c. } 2-3 \text {, p. } 562 \text { b }-563 \text { a }\end{array}$ & $\begin{array}{l}\text { III.657B- } \\
658 \text { A.CD-659A }\end{array}$ \\
\hline 110D & Albert the Great, Super DCH, 12, p. 179, l. 19-21 & $\mathrm{n} / \mathrm{a}$ \\
\hline [E8] 114B & $\begin{array}{l}\text { Ulrich of Strassburg, De summo bono, II, tr. } 5 \text {, } \\
\text { c. } 16,(1) \text {, p. } 108, \text { l. } 2-10\end{array}$ & I. $45^{2 \mathrm{C}}$ \\
\hline 163D & $\begin{array}{l}\text { Albert the Great, Super DDN, 4.11-12, p. } 120 \text {, } \\
\text { l. 9-17; p. 122, 1. 8-10 }\end{array}$ & $\mathrm{n} / \mathrm{a}$ \\
\hline
\end{tabular}

It is important to observe how Berthold reads and presents the scholia which he receives entirely through secondary sources. The following is a clear example, where Albert in his Summa theologiae is discussing Dionysius, De divinis nominibus 5.5, 820D.

$\begin{array}{lll}\text { Berthold of Moosburg, Expos. } & \begin{array}{l}\text { Albert the Great, Summa the- } \\ \text { ologiae }\end{array} & \begin{array}{l}\text { Dionysius, De divinis } \\ \text { 64C (p. 195, l. 83-102) }\end{array}\end{array}$

Super quo sic dicit Maximus in commento: "In monade quidem vi et potestate sunt numeri in generibus vero et formis actu et operatione. Vis autem eorum est substantialis eorum virtus, qua aeternaliter et incommutabiliter in monade existunt. Potestas vero eorum est possibilitas
Super idem dicit Maximus in commento: "In monade quidem vi et potestate sunt numeri, in generibus vero et formis actu et opere. Vis autem eorum substantialis, est eorum virtus qua aeternaliter et immutabiliter in monade existunt: potestas vero eorum est possibilitas eis insita, qua
In monade quidem vi et potestate sunt numeri, in generibus vero et formis actu et opere. Vis autem eorum est substantialis eorum virtus, qua aeternaliter et immutabiliter in monade subsistunt. Potestas vero est possibilitas eis insita, qua in genera et species

31 Albert the Great, Summa theologiae Ia, tr. 13 , q. 55 , m. 2, a. 2, s.c. $2-3$, p. 562b-563a. The scholium is also found, but only with minor variants, in Summa theologiae IIa, tr. 4, q. 14, m. 3, a. 2, part. 1, p. $177 \mathrm{~b}-178 \mathrm{a}$. 
(cont.)

Berthold of Moosburg, Expos. 64C (p. 195, 1. 83-102)
Albert the Great, Summa theologiae
Dionysius, De divinis nominibus, Ms Paris, BnF, lat. 17341, f. $249^{\text {rb-va }}$ eis insita, qua in genera et species possunt multiplicari et intellectibus propriis manifesti fieri, certis terminorum definitionibus, quantitatum diversitatibus, intervallis differentiarum, proportionarum proportionalitatum mirabili aequalitate et insolubili consonantia." Et subdit huiusmodi rei exemplum sic dicens: "Actus intellectus in monade numeros accipientis est motus animi purissimos in sua natura numeros absque ulla imaginatione intuentis. Opus vero, scilicet quo eosdem numeros ponit in speciem, est animi motus purissimos numeros, quos in se ipso considerat, phantasiis veluti quibusdam corporibus incrassatos memoriae commendantis ibique ordinantis, eorum rationes facilius tractantis forasque quibusdam signis corporalium sensuum significatos in aliorum notitiam tradentis. Intellectuales ergo numeri ex monade se diffundunt, ut in animo quodam modo splendescant. Deinde ex animo in rationem profluentes apertius se patefaciunt. in genera et species possunt multiplicari, et intellectibus propriis manifeste fieri certis terminorum diffinitionibus, quantitatum diversitatibus, intervallis differentiarum, proportionum proportionalitatumque mirabili aequalitate et insolubili consonantia." [...].

\section{Adhuc, Maximus ibidem} dans huius res signum, dicit sic: "Actus intellectus in monade numeros accipientis, est motus animi purissimos in sua natura numeros absque ulla imaginatione intuentis. Opus vero quo scilicet eosdem numeros ponit in speciem, est animi motus, purissimos numeros quos in seipso considerat, phantasiis veluti quibusdam corporibus incrassatos memoriae commendantis ibique ordinantis, eorumque rationes facilius tractantis, forasque quibusdam signis corporalium sensuum significatos in aliorum notitiam tradentis. Intellectuales ergo numeri ex monade se diffundunt, ut in animo quodammodo splendescant: deinde ex animo in rationem profluentes aper- possunt multiplicari et intellectibus manifesti fieri certis terminorum distinctionibus, quantitatum diversitatibus, intervallis differentiarum, proportionum proportionalitatumque mirabili aequalitate et insolubili consonantia.

Actus est motus animi purissimos in sua natura numeros absque ulla imaginatione intuentis.

Opus vero est eiusdem animi motus purissimos numeros, quos in seipso considerat, phantasiis veluti quibusdam corporibus incrassatos memoriae commendantis ibique eos ordinantis eorumque rationes facilius tractantis forasque quibusdam signis corporalium sensuum significatos in aliorum notitiam tradentis. Intellectuales ergo numeri ex monade se diffundunt, ut in animo quodam modo splendescant. Deinde ex animo in rationem profluentes apertius se patefaciunt. Mox de ratione in memoriam decur- 
(cont.)

\section{Berthold of Moosburg, Expos. Albert the Great, Summa the- Dionysius, De divinis 64C (p. 195, 1. 83-102) ologiae \\ nominibus, Ms Paris, BnF, lat. 17341, f. $249^{\text {rb-va }}$}

Mox de ratione in medullam decurrentes phantasticas ex ipsius memoriae natura excipiunt apparitiones, in quibus virtutes multiplicum suarum formarum inquisitionibus suis latenter aperiunt. Deinde in sensus sive sensibiles qualitates. Postremo in figuras eo, quod diversitatem figurarum exigit diversitas specierum." tius se patefaciunt: mox de ratione in memoriam decurrentes, phantasticas [ex] ipsius memoriae natura excipiunt apparitiones, in quibus virtutes multiplicium formarum suarum inquisitionibus suis latenter aperiunt: deinde in sensus sive sensibiles qualitates: postremo in figuras: eo quod diversitatem figurarum exigit diversitas specierum." rentes, phantasticas ex ipsius memoriae natura excipiunt apparitiones, in quibus virtutes multiplicium suarum formarum inquisitionibus suis luculenter apperiunt: deinde in sensus, postremo in figuras.

The variants and divisions in the text show that Berthold relies on Albert's Summa. Berthold's way of citing the text, adding in subdit, gives the impression that he has the text in front of him. A similar case is found in Prologus 4, where the divisions in Berthold's citations of Maximus correspond to Albert's list of arguments found shortly before the passage from the Summa used here, in $64 \mathrm{C} .{ }^{32}$

A more illustrative example clarifies Berthold's scholarly approach to these indirect sources: he not only embellishes passages found in Albert and Ulrich with information from the Clavis (i.e., Maximus monachus); he combines Theodorus and these intermediaries to conjecture about the content of a commentary on Dionysius written by Maximus which he believes that Theodorus, Albert and Ulrich are using. This more complex point requires that we consider three passages in sequence.

The first text comes from 14E:

$3^{2}$ Prologus 4, p. 10, l. 155-174 and Albert the Great, Summa theologiae, Ia, tr. 13, q. 55, m. 2, a. 1, 559b-56oa. 
Et secundum hoc Maximus, commentator Dionysii, super 9 cap. De divinis nominibus ponit tres motus descriptiones, ut testatur Theodorus in Clave dicens: [1] "Motus est virtus naturalis ad suum principium festinans"; [...] [2] "Motus est passio ex altero veniens ad alterum, cuius finis est impassibilitas"; [...] [3] "Motus est operatio activa, cuius finis est per se ipsam perfectio." 33

All three definitions of motion are found, as Berthold says, in the Clavis which, however, contains no mention of De divinis nominibus $9 .{ }^{34}$ The link is made through Albert, who gives [1] in identical form, followed by a second definition effectively combining [2] and [3], and relates them to a precise passage in Dionysius: Commentator ponit hic duas diffinitiones motus. ${ }^{35}$ Berthold's reliance on Albert, rather than his own familiarity with the Dionysian text, is confirmed by his use of Albert's glosses on these commentaries, which he includes and embellishes after each supposedly Maximian definition. Berthold therefore notes the parallels between Albert's commentary and the Clavis and, in his own synthesis of these sources, assumes that Theodorus is witnessing (testatur) to a commentary by Maximus on Dionysius.

The same approach is developed in 16A:

Sic enim Maximus, commentator Dionysii, definiens motum dicit, quod "est virtus naturalis ad suum principium festinans". "Amor" nempe secundum eundem ibidem "est naturalis motus omnium rerum, quae in motu sint, finis quietaque statio, ultra quam nullus progreditur naturae motus," sicut allegat ipsum Maximum Theodorus in Clave. ${ }^{36}$

33 Expositio 14E, p. 7, 1. 142-144, 146-147, 154-155.

34 Clavis 65, p. 45, 1. 3-6: Naturalis motus, teste Maximo, tripliciter diffinitur sic: "Motus est virtus naturalis ad suum finem festinans, vel motus est passio ex altero veniens ad alterum cuius finis est inpassibilitas, vel motus est operatio activa cuius finis est per se ipsam perfectio".

35 Albert the Great, Super De divinis nominibus, 9.21, p. 390, 1. 11-15: Commentator ponit hic duas diffinitiones motus. Prima est: "Motus est virtus naturalis ad suum festinans finem"; secunda est: "Motus est passio ex altero veniens ad alterum, cuius finis est per seipsam perfectio". The scholium reads: Motus naturalis tripliciter ita diffinitur: Motus est virtus naturalis ad suum festinans finem, vel sic: Motus est passio ex altero veniens ad alterum, cuius finis est impassibilitas, aut sic: Motus est operatio activa [ed. auctiva], cuius et finis est per seipsam perfectio.

$36 \quad$ Expositio 16A, p. 24, l. 26-31. 
This definition of motion appeared first in $14 \mathrm{E}$, taken from Albert and the Clavis, which Berthold now attributes to "Maximus the commentator of Dionysius". He then gives a definition of amor, taken from a later passage (Clavis 67), following another definition of love which Berthold does not cite. ${ }^{37}$ However, neither definition of amor is attributed to Dionysius or Maximus in the Clavis, though both definitions are incorporated as "Maximian" scholia by the 13thcentury Excerptor of the Periphyseon and are subsequently attributed to the "Commentator" by Albert, Ulrich and Thomas Aquinas. ${ }^{38}$ Once again, likely following Albert's lead, Berthold assumes Maximus's authorship of the definition of amor and then presents Theodorus as simply recounting (allegat) Maximus's putative commentary on Dionysius. ${ }^{39}$

Berthold's strategy is clearest a few lines below, in 16B:

Amor enim secundum Dionysium ubi supra R, sicut allegat eum Maximus, prout recitat Theodorus in Clave, [A] "est simplex quaedam virtus se ipsam movens ad unitivam quandam temperantiam ex optimo existentium usque ad novissimum et ab illo iterum consequenter per omnia usque ad optimum, ex se ipsa et per se ipsam et ad se ipsam se ipsam revolvens et in se ipsa eodem modo semper revoluta. [в] Merito ergo Deus amor dicitur, quia omnis amoris causa est et per omnia diffunditur et in unum colligit omnia et ad se ipsum ineffabili regressu revolvitur totiusque creaturae amatorios motus in se ipsa terminat." ${ }^{40}$

In the Clavis 67, immediately after the definition just cited in Expositio 16A, the author introduces this definition of amor [A] with the words Dyonisio autem

37 Clavis 67, p. 46, 1. 4-8: Primum diffinitionem amoris accipe: amor est conexio et vinculum quo omnium rerum universitas ineffabili amicitia insolubilique unitate copulatur, vel amor est naturalis motus omnium rerum que in motu sunt, finis quietaque statio ultra quam nullus creature progreditur motus.

38 Albert the Great, In III Sententiarum, d. 27, a. 4, p. 517b; Thomas Aquinas, In III Sententiarum, d. 27, q. 1, a. 2, obj. 2, p. 859; Ulrich of Strassburg, De summo bono II, tr. 3, c. 6, (4), p. 71, l. 71-76. An important exception is Albert the Great, Summa theologiae, Ia, tr. 6, q. 26, c. 1, part. 4, p. 179, l. 73-81 which incorrectly distinguishes two authors: Maximus episcopus as author of Amor est conexio, and Iohannes episcopus (a vestige of the attribution accompanying the scholia of John of Scythopolis translated by Anastasius) of Amor est naturalis motus. With the Clavis before him, Berthold may have Albert's split attribution in mind when adding the emphasis "nempe secundum eundem ibidem".

39 In Expositio 39D, p. 32, l. 52, Berthold attributes this definition of amor to many (quibusdam).

$40 \quad$ Expositio 16B, p. 26, 1. 87-95. 
diffiniente.$^{41}$ According to Berthold, Theodorus simply "repeats" (recitat) Maximus in this chapter, who in turn "relates" (allegat) the view of Dionysius. In other words, he assumes the phrase Dyonisio autem diffiniente is copied directly from a text written by Maximus.

To connect this with a specific passage in Dionysius ("supra R"), Berthold finds no hints in Clavis 67 and the other sources used in 16в. It seems he has detected similarities between the Clavis and the translation of Dionysius by John Sarracen. What the Clavis transmits from [A] is Eriugena's own translation of Dionysius. ${ }^{42}$ The text which follows from [B], however, is not a translation of Dionysius, but a continuation of Eriugena's analysis from the Periphyseon (I.519D-520A). The text from [B] had been introduced as a scholium in the Parisian Corpus, adjacent to Eriugena's translation of the passage in Dionysius. ${ }^{43}$ I have not found any candidate as an intermediate source for this scholium. Rather, it seems that Berthold applies his conjecture about Maximus's authorship to the entire passage. Had he in fact read the scholia firsthand, he would know that Maximus is not the author of text $[\mathrm{A}]$ and would likely have signalled the text as the alia translatio of Dionysius, as is his practice.

Finally, concerning the two non-Eriugenian commentaries attributed to Maximus, at least one comes from Thomas of York's Sapientiale. ${ }^{44}$ Thomas only mentions the Commentator who, in this case, is in fact Thomas Gallus, though Berthold assumes that this is also referring to Maximus.

41 Clavis 67, p. 46, 1. 8 f.: Dyonisio autem diffiniente, amor est simplex quedam virtus se ipsam movens [...].

42 Dionysiaca I, 2291-2301. For Sarracen's translation, see Dionysius, De divinis nominibus 4.17, 713D (in Albert the Great, Super DDN 4.141, p. 229, 1. 69-72): [...] quod una quaedam est simplex virtus per se motiva ad unitivam quandam concretionem, ex bono usque ad extremum existentium et ab illo rursus consequenter per omnia ad bonum, ex eadem et per eandem et in eadem seipsam reflectens et ad eandem semper eodem modo revoluta.

43 Of the ninety-nine glosses added to the Parisian Corpus deriving from the Periphyseon, according to Dondaine's count, "bon nombre d' entre elles s' imposaient d' elles-mêmes à l' attention du Compilateur en quête de gloses sur Denys: à savoir, les pages où Érigène cite et commente Denys avec référence précise" (Dondaine 1953, p. 85).

44 On Berthold's extensive debts to Thomas, which is still yet to be fully reckoned, see Fiorella Retucci's notice in her edition, Berthold von Moosburg 2007, p. xxii-xxxix; Retucci/Goering 2010; and Retucci's contribution to this volume. 


\section{Berthold of Moosburg, Expo- Thomas of York, Sapientiale sitio, 16B (p. 26, 1. 75-85) I. $^{45} 7^{46}$ \\ Thomas Gallus, Explanatio, c. 4 , p. $1646-1654$}

Nam inquantum [Deus] amor est, movetur in dilecta, hoc est in producta, inquantum autem amabile est, convertit seu movet ea, quae producta sunt, in se ipsum, ut ipsum diligant seu ament, quia bonum et pulchrum omni existenti naturaliter sunt appetibilia. Movetur sicut sui ipsius ad omnia communicativum, movet sicut omnium ad se adductivum et conversivum vel reductivum et ita, quod amor movetur in omnia, quia amabile movet ad se omnia, quia amor est procedens, quia amabile sursum agens et omnia in se reflectens: haec est enim natura amoris, sicut dicit ibi Maximus, appetere reflexionem. Et propter hoc divinus amor comparatur circulo propter hanc interminabilem reflexionem seu revolutionem ipsius prime boni in omnia et omnium in ipsum, sicut dicit ibi Dionysius.
Secundum Dionysium De divinis nominibus cap. 4 [...] Nam inquantum amor est, movetur in dilecta, hoc est in ea que facta sunt. Inquantum autem amabilis est, movet ea que facta sunt in se ipsum, ut eum diligatur per bonum et pulchrum, que omni existenti naturaliter sunt appetibilia, movetur sicut sui ipsius ad omnia communicativus, movet sicut omnium ad se adductivus et conversivus vel reductivus. Et ita quia amor movetur in omnia, quia amabilis movet ad se omnia, sicut magnes attrahit ad se ferrum, quia amor est procedens, quia amabilis sursum agens et omnia in se reflectens. Hec est enim natura amoris appetere amoris reflexionem, sicut dicit ibidem expositor. Et ideo dicit in Prov. 8: "Ego diligentes me diligo". Et propter hoc comparatur divinus amor circulo, propter hanc interminabilem revolutionem
ET HOC, scilicet amor siue dilectio, MOVETUR in dilecta [...]. Hic uidetur assignare potius quare dicitur Deus amabilis quam quare amor iuxta predicta, sed addit de amoris uirtute que nondum dixerat, scilicet quod natura amoris est appetere amoris reflexionem. Diligi enim uolumus ab hiis quos diligimus: Prou. 8d: Ego diligentes me diligo etc. Et hoc est quod Deus dicitur amor tamquam in res procedens et iuxta amoris naturalem requisitionem procedendo, omnia in Deum appetendum mouens, reflectens, SICVT VIRTVS SVRSVMAGENS ET BONVS PROCESSVS reflexiuus omnium AD SE IPSVM. [...] Circulus ergo diuino amori comparatur quia amor diuinus $[\ldots]$.

45 Cf. Expositio 23I, p. 122, l. 357-374.

46 A portion of this passage is tacitly copied from Thomas of York by Berthold at Expositio 146 H, p. 95 , l. 173-p. 96, l. 182, but without an attribution to Maximus. I wish to thank Fiorella Retucci, the editor of this text, for allowing me to use the resources of the editorial project of Thomas of York's Sapientiale underway at the Thomas-Institut (Cologne) under her direction. 
(cont.)

Berthold of Moosburg, Expo- $\quad$ Thomas of York, Sapientiale sitio, 16в (p. 26, l. 75-85)
I.17

Thomas Gallus, Explanatio, c. 4, p. 1646-1654

\section{ipsius in omnia et omnium \\ in ipsum, sicut dicit ibidem \\ Dionysius, quod divinus amor \\ est sicut quidam eternus cir- \\ culus, propter bonum ex bono, \\ in bono et ad bonum in non \\ errante convolutione circum- \\ ambulans.}

One can conclude definitively that Berthold does not know the scholia firsthand; he uses Albert the Great, Ulrich of Strassburg, the Clavis and Thomas of York together to assemble passages from a supposed commentary of Maximus monachus on Dionysius.

Berthold almost certainly knows some version of the Corpus Dionysiacum directly, primarily through John Sarracen's translation and supplemented, regularly for certain phrases, with Eriugena's translation, when its terminology agrees more literally with the Latin text of William of Moerbeke's Proclus. Nevertheless, Albert's commentaries are always close at hand. A suggestive example is a citation of De mystica theologia (DMT) where Berthold includes a variant, alia translatio: circa mysticos intellectus. ${ }^{47}$ This other translation is not Eriugena's but rather the text presented in Albert's commentary where, in the course of his divisio textus, he simply gives the phrase without noting it as a variant. ${ }^{48}$ It seems more likely that Berthold notices the variant in Albert's commentary, though perhaps Berthold and Albert use a related, or identical, copy of Dionysius. Another instructive variant taken from Albert is found in Prol. 4, in a lengthy citation of De divinis nominibus 11.6, where Berthold's participabiliter instead of Sarracen's participaliter (for $\mu \varepsilon \theta \varepsilon \varkappa \tau \omega \varsigma$ ) seems to agree with the text Albert comments upon. ${ }^{49}$ Elsewhere, however, when citing the same pas-

$47 \quad$ Expositio 202A, p. 181, 1. 28-29.

48 Albert the Great, Super DMT, c. 1, p. 457, 1. 42-46: Modus autem, quem docet Timotheum, cui scribit, qui tenet formam discipuli, est, ut circa intellectus mysticos relinquat sensus et intellectuales operationes forti contritione, quasi conterendo sub lumine divino [...].

Prologus 4, p. 10, l. 179; Albert the Great, Super DDN, 11.27-28, p. 424, 1. 73-74 and p. 425, 
sage, Berthold gives Eriugena's faulty alternative, particulariter.$^{50}$ These variants would justify a closer examination of the manuscripts of Albert's commentaries on Dionysius, which may provide further insight into the state of the Corpus Dionysiacum known to Berthold.

\subsection{Origenes, Chrysostomus}

Berthold follows the majority of the manuscript tradition and attributes Eriugena's Homily on the Gospel of John (870-872) to Origen. ${ }^{51}$ There is only one explicit quotation of the Super Ioannem in the Expositio, which compresses chapters 9 and 10 of the text..$^{52}$ The passage treats John 1:4 (Quod factum est in ipso, vita erat) using analogies drawn from nature. Creatures subsist in a causal mode (causaliter) in the Word before they appear as effects, just as all things in this world subsist uniformly in the Sun, as the diversity of herbs and fruits are contained in their seeds, as the diversity of crafts are one and alive in the mind of the craftsman, or as an infinite number of lines subsists in the point. The passage concludes:

Et huiusmodi naturalia perspice exempla, ex quibus velut physicae theoriae pennis poteris arcana verbi mentis acie inspicere et, quantum datur humanis rationibus, videre, quomodo omnia, quae per verbum facta sunt, in ipso vivunt et facta sunt! ${ }^{53}$

This combined approach to nature and Scripture corroborates much of what Berthold would read about Origen in the Clavis physicae: "blessed Origen," "the most diligent enquirer into things" and "highest expositor of Scripture". 54 This limited source of Eriugenian influence converges with the broader stream coming through the Clavis and Maximus, where the relationship between a causal, enfolded unity and an effected, explicated multiplicity is discussed frequently using analogies drawn from nature. ${ }^{55}$

1. 41; cf. p. 422, 1. 69. This variant is highly advantageous for the doctrine of the primordial causes outlined in Prologus 4.

50 Expositio 63B, p. 187, l. 35-p. 188, l. 40; 113A, p. 34, l. 35-40. See Dionysiaca I.5221.

51 Mainoldi 2005, p. 228-234.

52 Expositio 30D, p. 196, l. 200-215.

53 Expositio 3OD, p. 196, 1. 212-215.

54 Clavis 387 (p. 121, l. 1899): beatum Origenem (cf. Periphyseon v.922C); Clavis 397 (p. 129, l. 2173-2175): magnum Origenem, diligentissimum rerum inquisitorem (cf. Periphyseon v.929A); Clavis 284 (p. 231, l. 6-7): Origenes namque, summus sacre Scripture expositor (cf. Periphyseon IV.818B).

55 Similar analogies are drawn from the Clavis elsewhere - the point, the seed, the simple 
A similar doctrine is attributed by Berthold to Chrysostomus, using the analogy of the sun to illustrate the pre-existence of species in the eternal, living Word. ${ }^{56}$ His proximate source for this is Thomas of York. ${ }^{57}$ The original source, again, is chapter 10 of Eriugena's Homily. ${ }^{58}$ Five of the manuscripts discussed by Édouard Jeauneau attribute the work to Ioannes episcopus which, for medieval readers, is John Chrysostom, and two explicitly attribute it to the saint. ${ }^{59}$

\section{$1.4 \quad$ Alfarabius}

Berthold draws from four chapters from what he sometimes calls the De causa causarum, known today as the De causis primis et secundis et fluxu qui consequitur eas, a total of five times (Prol. 4 [c. 2], 56D [c. 2, 4], 64C [c. 1], 99B [c. 1], $17 \mathrm{OH}\left[\right.$ c. 8]). ${ }^{60}$ The attribution to Al-Fārābì is unprecedented; the extant manuscripts of the De causis primis et secundis transmit the text either anonymously or attribute it to Avicenna. Whatever difference this makes is surely secondary to the striking assumption that either philosopher would cite Dionysius and Augustine with approval when promoting an account of the creation of all things in the primordial causes within God's Wisdom. ${ }^{61}$

Indeed, Berthold uses the text alongside Dionysius (99B) and sometimes also Maximus (Prol. 4, 64C), and almost always relative to the doctrine of the primordial causes (except for $17 \mathrm{OH}$ ). In $64 \mathrm{C}$ and $99 \mathrm{~B}$, he uses non-Eriugenian passages from the text regarding divine simplicity to elucidate the doctrine of the primordial causes or "unities". The selections from chapters 2 and 4 of the De causa causarum derive from passages in the Periphyseon concerning the status of the primordial causes, and the capacity of created intellect to know that they exist (quia) but not what they are (quid). These passages are modified by the author of the De causa causarum in important ways that are

four elements underlying the visible elements- to elucidate the unconfused, causal subsistence of diversity in unity: Expositio 176H (Clavis 155 and 316-317); 129A (Clavis 177, 179, 187, 188, 193 and 195).

$5^{6} \quad$ Expositio 176D, p. 165, l. 264-p. 166, 1. 270: [...] secundum Chrysostomum.

57 Thomas of York, Sapientiale I.29: [...] ex sermone sapientis Iohannis Chrysostomi. The text is edited in Retucci 2008, p. 104, l. $5^{2-58 .}$

58 Eriugena, Homily X.288D-289B, p. 246-252.

59 See Jeauneau's introduction to his edition of the Homily, p. 53-57. Thomas of York may have read a manuscript similar to that known to Robert Grosseteste, who makes the same attribution; see McEvoy 1987, p. 206-207.

6o De Vaux 1934, p. 83-140. Berthold uses no chapter divisions, and sometimes only gives the incipit: Principium principiorum Deus est gloriosus (Expositio 56D; 99B) or cites it under the name of Al-Fārābī (Expositio 170H).

61 D'Alverny 1973, p. 178. Cf. De causis primis et secundis, c. 2, p. 91, l. 1; c. 4, p. 105, l. 3; p. 105, l. 7 ; c. 7 , p. 113 , l. 4 ; c. 8 , p. 121, l. 5 . 
decisive for Berthold's preference for this work at times instead of the parallel text of the Clavis physicae. ${ }^{62}$

Among the other works attributed to Al-Fārābi in the Expositio is the De ortu scientiarum, used by Berthold to explain what is meant when the Hermetic Asclepius refers to the human as the ruler (gubernator) of the sensible world. Berthold introduces the figure of the astronomer-astrologer, who has knowledge of future events by a per se consideration of the first causes of natural things. He cites Al-Fārābī, "the wise man is the measure of all things, inhabiting the elements and parts of the world, acquiring the highest delights", and Proclus on divine union as "ruling the world with the gods".63 Thus Al-Fārābi and Proclus are brought together within the paradigm of the sapiens, astrologer or prophet who, by intellectual union with the primordial causes or gods, participates in their operative power.

Following a 13th-century convention, Berthold attributes the entire Liber de causis, propositions and commentaries, to Al-Fārābī. ${ }^{64}$ Interestingly, the lengthiest citation of the De causis primis is used in his comments to Proposition 56 of the Elementatio which, as Berthold notes, is the basis for Proposition 1 of the Liber de causis. ${ }^{65}$ Berthold's use of the Liber de causis is quite restricted and his appreciation of it is ambiguous. At one point, he criticises it with the words of Dionysius in De mystica theologia, who identifies the unlearned as those who are "sealed off among beings", since it asserts that the first of created things is being. ${ }^{66}$ Berthold, however, acknowledges the agreement between the De causis primis and Maximus ${ }^{67}$ and, by extension, with Dionysius, on the doctrine of the primordial causes. Al-Fārābī stands on both sides of the divide of Platonists and Aristotelians. Whether or how Berthold resolved this duplicity in his sources is unknown.

62 On the importance of the De causis primis et secundis for the doctrine of the primordial causes, see Ludueña, 2013a, p. 253-256, 327-333; 2013b, p. 115-125. Periphyseon, II.55oc551A.552A and II.553BC are compressed significantly in Clavis 86, p. 61, l. 2-19 and 87, p. 62, l. 10-13, respectively. Berthold leaves a marginal cross next to Clavis 86 (Ms Paris, BnF, lat. 6734, f. 35 ${ }^{\mathrm{v}}$ ) and cites 87 three times (Prologus 9; Expositio, 18в; 126в).

63 Prologus 16, p. 24, l. 636-p. 25, 1. 646.

64 See the table of philosophers preceding the Prologus in the CPTMA edition $(4,40-41)$ : Alfarabius De causa causarum / item De causis; cf. Expositio 166в, p. 49, l. 89-9o: [...] Alpharabium super 3 prop. De causis per propositiones, quas ponit ibidem.

65 Expositio 56D, p. 143, l. 101-105.

66 Expositio 71D, p. 35, l. 123-127.

67 Expositio 64C, p. 195, l. 103: Praemisso exemplo concordat Alfarabius De causa causarum cap. 2. 
From the foregoing, it is clear that Berthold is not concerned with the thought of a Latin author named John Scotus Eriugena. To grasp the doxographical outlook behind the Expositio, one must imagine Theodorus to be an inheritor of a longer Greek tradition of Dionysian theology, giving access to authorities such as Maximus who, as the Clavis reports, transmits teachings handed down from the Apostles. ${ }^{68}$ It also unifies the Greek Fathers with Augustine under the common banner of Platonism which it is the goal of the Expositio to elucidate. If there is one doctrine common to these four relatively rare Eriugenian sources, it is the theory of the essential causality operated by primordial causes which both remain within and proceed from the Word, ${ }^{69}$ which provides the philosophical means of reconciling Proclus, Dionysius and Augustine. ${ }^{70}$ As Eriugenism draws nearer to the origins of Dionysian theology, Proclus, one of the greatest representatives of pagan Platonism, is brought into even closer agreement with the convert and disciple of St. Paul. The commentator's sight is set on an ancient "Golden Age". ${ }^{71}$ One can only add that Eriugenism has played an essential role in establishing peace within that Golden Age. We shall now see precisely how Eriugenism provides the philosophical means for reconciling Proclus and Dionysius relative to one of the most challenging doctrines in the Elementatio theologica.

\section{Doctrine}

After the combined influence of the four branches of Eriugenism on Berthold's exposition of the Proclean gods, the second most important area of Eriugenian influence depends only on the Clavis physicae. This concerns the theory of the

68 Clavis 69, p. 48, 1. 4-5: Maximus philosophus tradit a successoribus apostolorum omnium que sunt quinquepertitam divisionem [...].

69 Cf. Expositio 176c, p. 163, l. 206-p. 164, l. 213: Verum ut ista diversitas excludatur, sciendum, quod principale exemplar simplex est intra omnium causam, scilicet prime Deum sive eius mentem secundum Dionysium, Augustinum, Boethium et Platonem cum suis sequacibus, ut iam diffuse ostensum est, exemplaria vero sub primo principali exemplari, quae et ipsa dicuntur et sunt causae primordiales rerum sicut ipsi dii, non quod prime Deus ad extra respiciat in universum producendo, sed quia in eis et per ea determinat suam causalitatem utens eis quasi pro instrumento operationis suae.

$70 \quad$ Gersh 20o1, p. 497: "Clearly Berthold could not have worked out so successfully the rapprochement between Proclean noetic principles, Pseudo-Dionysian divine attributes, and Augustinian eternal reasons without recourse to the Eriugenian doctrine of primordial causes and their effects".

$71 \quad$ Sturlese 2013, p. 102. 
paradisal and resurrected body. In Proposition 196, one finds the most intensive concentration of passages from the Clavis in the entire commentary:

Omnis anima participabilis corpore utitur primo perpetuo et habente hypostasim ingenerabilem et incorruptibilem.

Every participable soul—a term including both heavenly ("total") and human ("partial") souls-first uses a perpetual body which has its existence beyond generation and corruption. Berthold discusses the cases of heavenly and human souls separately, at $196 \mathrm{D}-\mathrm{E}$ and $196 \mathrm{~F}$, respectively. When treating heavenly souls, his main sources are Dietrich of Freiberg and Averroes, and for human souls, the Clavis. Their distinctive lines of argument result in a tension in Berthold's account in 196 which is not resolved, or even addressed, until Propositions 206-211.

In 196F, Berthold carefully selects from twelve chapters in the Clavis, citing one-hundred and fifteen lines in total, which amount to a concise presentation of Eriugenian anthropology. As he presents it, the question of the nature of spiritual body in the Clavis arises out of a reflection on the status of the human as imago Dei. The imago, as he reads in the Clavis, includes everything in human nature that is substantial and abiding in the eternal present of God's creative Word. ${ }^{72}$ Accordingly, it does not include the corruptible body that is extraneous to the intelligible essence of the human, but rather the spiritual body, which was created in Paradise, which abides and which will exist after the Resurrection (Clavis $\left.93^{-} 95\right) \cdot{ }^{73}$

Primum illud essentiale corpus in paradiso est conditum; sola tamen ratione et anima in ipso generali et universali homine ad imaginem Dei facto creata est, in quo omnes homines secundum corpus et animam simul et semel in sola possibilitate conditi sunt et in ipso omnes peccaverunt, priusquam in proprias substantias prodirent, id est antequam quisquam in discreta differentia in anima rationali et spirituali corpore

72 Crouse 2002, p. 307-309.

73 Expositio 196F, p. 127, l. 148-152 = Clavis 95: Corpus autem dico hoc corruptibile carnalis adhuc animae merito suae inoboedientiae superbiaeque diversisque calamitatibus involutae hospitium, non illud caeleste et spirituale, quod in paradiso cum animae creatum est, quale et post resurrectionem futurum erit. Cf. Expositio 210M, p. 255, 1. 321-324 = Clavis 246: Ibi enim intellectus, ibi ratio, ibi sensus, ibi seminalis vita, ibi corpus, non hoc corruptibile merito peccati superadditum, sed spirituale et caeleste ante delictum datum et in resurrectione futurum. 
appareret, quod corpus incorruptibili animae aeternaliter adhaereret, si non peccaret; et in hoc omnes homines resurrecturi sunt. ${ }^{74}$

The spiritual body belongs to "the general and universal human" in Paradise, prior to any divisions of time or place, prior even to human history and the division of the sexes, both of which result from the Fall. In the universal human, individuals are present only in possibility and have not yet gone forth into their proper substances, into distinct souls and spiritual bodies by angelic reproduction. ${ }^{75}$ Since Adam turned towards himself rather than to God, humanity in its fall constitutes for itself a corruptible body appropriate to that lower life. ${ }^{76}$

Berthold undoubtedly has discerned some similarities between Proclus's doctrine and this theory in the Clavis: the spiritual body is created by an immobile substance, while the lower body is superadded to accompany the soul's fall from being into becoming. ${ }^{77}$ Beyond this, however, the encounter of Eriugenism and Proclus becomes more volatile. This is apparent from two distinct but related problematics.

\subsection{Rejection of Metemsomatosis}

Berthold insists three times with the Clavis, correcting Proclus, that souls which enjoy blessedness can never fall. This is the only issue in the Expositio where Proclus is contradicted by the commentator. The correction is made at the conclusion of Proposition 196, again in 206, and finally in 209, as Berthold cites Theodorus on the beatitude "promised to the saints" and the reversion of all temporal things into their primordial causes, when "God alone shall appear in them". This passing into God transpires only when creatures doff the finitude of time and place and return to their infinite eternal principles. "By this," Berthold concludes, "the descent of souls is refuted yet again".78 However, the central refutation occurs in Proposition 206:

$74 \quad$ Expositio 196F, p. 128, l. 171-178 = Clavis 103.

75 The Clavis omits the more precise designation of this unachieved multiplication as a form of angelic reproduction. Cf. Periphyseon II.582B, p. 362, 1. 3975-3985: [...] priusquam in proprias substantias prodirent, hoc est, antequam unusquisque secundum angelicam multiplicationem in sua discreta differentia in anima rationali et spirituali corpore appareret.

76 Cf. Expositio 207E (with Macrobius, In Som. Scip. I.14.7) and 196F, p. 127, l. 154: [...] ostendit animam sibi ipsi causare corpus materiale.

$77 \quad$ Expositio $207 \mathrm{E}-\mathrm{F}$, p. 229, l. 151-p. 231, l. 213.

78 Expositio 196F, p. 170, l. 64-65 = Clavis, 103: Non autem video quomodo homo beatitudinem perderet si eam re ipsa plene perfecteque gustaret. Cf. Expositio, 206F, p. 223, l. 261-266: Istius autem descensus animarum vult auctor in infinitum vicissitudines permutari, quod non videtur intelligibile; anima enim fruens fonte omnium bonorum utpote beata et felicis vitae nec timore torqueri potuerit nec falsa securitate decipi nec commutabili bono allici ut, 
Omnis anima partialis descendere in generationem in infinitum et ascendere potest a generatione in ens.

In Proposition 206, Berthold's strategy is notably not to reject the doctrine of metemsomatosis outright, but to present the views of Proclus and Macrobius, his other principal source, in such a way as to accentuate the common aims on both sides. ${ }^{79} \mathrm{He}$ takes an interpretative framework from Albert's De natura et origine animae (II.7), where the Platonic soteriology of cyclical reincarnation is presented chiefly as an account of the soul's origin, its immortality and its yearning for contemplative perfection. Berthold thus interprets the Platonic doctrine of companion stars (stellae compares) as an expression of the proper home and destination of partial souls. Platonists speak this way, he explains, because of their account of the origin of the partial soul, which states that the constellations exercise a determinative operation through the influence of intellectual light, whereby a celestial mover scatters intellectual seeds proportionate to itself within the soul..$^{80}$ Embellishing what he takes from Albert, Berthold generously claims that this view accords with the theologians who say that "souls are poured in by being created and are created by being poured in" (creando infundi et infundendo creari).${ }^{81}$ Thus the basic Platonic position is freed of any association with the doctrine of a literal pre-existence of the souls, and the disagreement with Proclus, though substantial, is made as unobtrusive as possible.

He then describes the soul's proper activity (operatio) within its native place. The views of Proclus and Dionysius are presented as compatible though, in

volens, a bono incommutabili se avertat nec ad aversionem ab aliquo violentari. Also Expositio 209 F, p. 245, l. 201: [...] per hoc iterum refellitur descensus animarum.

79 In his glosses on the In Somnium Scipionis, Berthold connects Macrobius and Proclus on this doctrine. Ms Basel, Universitätsbibliothek, F.IV.31, f. $13^{\text {r }}$ (In Somn. Scip., I.9.1): 〈ANIMARVM ORIGINEM MANARE DE CAELO Proclus in Elementatione theologica 206a propositione et usque ad finem prosequitur istam materiam. On this manuscript, see De animabus, p. xxiv-xlii, lxii-lxvi.

8o This approach takes up from Macrobius, In Somn. Scip. I.14, whom Berthold cites on the "fiery" intellect which the souls receive from the higher stars of the Milky Way (207E), which appears alongside Boethius' poetic images of recollection as glowing embers kindled by teaching $(207 \mathrm{~A}-\mathrm{C})$.

81 Expositio 2068, p. 217, 1. 51-54: Et in talem sententiam concordant etiam isti, qui dicunt animas creando infundi et infundendo creari ita, quod usque hodie in circulis nativitatem ponitur ab eis una stella, quam Hyleg et Alkocoden vocant, quod Latine sonat vita et intellectus, eo, quod nato vitam et intellectum conferre dicitur. Cf. Expositio, 207C, p. 227, 1. 78-82. The remote source of the phrase is Peter Lombard, Sententiarum II, d. 17, c. 3: creando enim infundit eas Deus, et infundendo creat. 
fact, they quite strongly opposed, as Jean Trouillard has argued in a comparison of Eriugena and Proclus on precisely this point. ${ }^{82}$ Trouillard explains how, for Proclus, separated souls rejoice at the prospect of being reunited with a body. Virtuous and vicious souls alike find in their return to body the opportunity for action, though they descend for different reasons. Berthold himself is aware of this idea, according to which souls descend either from "inability to imitate the presiding [gods], desire for noble birth, purity, virtue [or] divine intellect". ${ }^{83} \mathrm{He}$ even cites the passage which, according to Trouillard, one would have to identify as distinctively Proclean:

Non enim erat prime bonum thea, id est speculatio, vel intellectualis vita et prudentia, ut alicubi ait aliquis, sed quod secundum divinum intellectum detinens quidem intellectualia sui ipsius intellectu. Ambiens autem sensibilia his quae alterius potentiis et eorum quae inde bonorum partem etiam ipsius his exhibens, quia, quod perfecte bonum non in salvare se ipsum solum habet le plenum, sed iam et ea, quae ad alia datione et non invidiosae operationis omnia bonifacere desiderat et sibi similia facere. ${ }^{84}$

Unlike Trouillard, however, Berthold, would not abide the sharp separation of Proclus and the greatest of Christian Platonists. So he emphasises another aspect of this passage, where Proclus describes how the blessed souls "feast" with the gods, and draws a very different, even opposed, conclusion to that of Trouillard. The language of feasting, Berthold contends, suggests that we are dealing with an activity which is connatural to the soul; the feast will be the reward of those souls which aspire to assimilation and unity with God through the one in the soul. ${ }^{85}$ If ever a soul delights in the immutable fount of all goods,

\footnotetext{
$82 \quad$ Trouillard 1984.

$83 \quad$ Expositio 206D, p. 220, 1. 140-142.

84 Expositio 206c, p. 218, l. 83-89 = Proclus, De malorum subsistentia 7.23, p. 202, l. 10-18. The translation of Opsomer/Steel 2003, p. 73-74: "For the primary good is not contemplation, intellective life, and knowledge, as someone has said somewhere. No, it is life in accordance with the divine intellect which consists, on the one hand, in comprehending the intelligibles through its own intellect, and, on the other, in encompassing the sensibles with the powers of [the circle of] difference and in giving even to these sensibles a portion of the goods from above. For that which is perfectly good possesses plenitude, not by the mere preservation of itself, but because it also desires, by its gift to others and through the ungrudging abundance of its activity, to benefit all things and make them similar to itself".

85 Expositio 206c, p. 218, 1. 91-p. 219, l. 101: Ex quibus verbis [Procli] aperte colligitur animam partialem, ut est in ente, esse beatam, sicut quae cum diis praesidibus ascendit ad felicem et perfectissimam entis epulationem, id est ad fruitionem divinorum et specialiter prime boni; hoc enim per epulationem talem signanter, sicut ostendit Dionysius [...] et divino nutrimento
} 
nothing could draw it away. ${ }^{86}$ Thus the language of metemsomatosis and the soul's pre-existence is treated as a kind of integumentum concealing the truth that the perfection of the soul consists in the stability of contemplation. This theory is more Eriugenian than Proclean; for Eriugena, as Trouillard notes, the perfection of the soul is to be "saturated by contemplation".87 Proclus is made to agree with the Platonic consensus, according to Berthold, through Dionysius, whom he cites for the notion of being "filled with most holy contemplations" when we shall be "sons of the Resurrection" and "equal to the angels".88

\subsection{The Spiritual Body}

Et attende: Quod auctor vocat susceptaculum, Apostolus vocat domum seu habitaculum. 89

It is a principle for Proclus that from a transcendent, unparticipated Monad a group of immanent, participated terms arises. The multiplicity of that group in turn reflects the diversity of participants. In this case, the differentiation of participable souls appears simultaneously with bodies to participate them, ${ }^{90}$ such that the incorruptible vehicle of the soul accounts for an individual soul's distinction from the Monadic, unparticipated Soul. If participable souls depend on a body for their individuation, there must be an imperishable principle coinciding with soul's own immortality. In his Timaeus commentary, where he develops the doctrine most extensively, Proclus posits a permanent "astral" body which guarantees the immortal soul's singularity throughout the great

adimpletus, multa quidem, primo data effusione, una autem, invariabili et vivifica thearchicae epulationis unitate. Cf. Expositio 207B, p. 226, 1. 63-p. 227, l. 70; 209A, p. 24O, 1. 21-31; 209E, p. 244, l. 158-171; 210L, p. 255, l. 304-307.

86 Expositio 206F, p. 223, 1. 263-266: [...] anima enim fruens fonte omnium bonorum utpote beata et felicis vitae nec timore torqueri potuerit nec falsa securitate decipi nec commutabili bono allici ut, volens, a bono incommutabili se avertat nec ad aversionem ab aliquo violentari.

87 Trouillard 2014, p. 532.

88 Expositio 185H, p. 24, l. 334-p. 25, l. 365; 202C, p. 185, l. 127-136: [...] quando incorruptibiles et immortales erimus et christiformem et beatissimum consequemur finem, visibili ipsius Dei apparitione in castissimis contemplationibus adimpleti, manifestissimis circa nos splendoribus refulgente, sicut circa discipulos in illa divinissima transformatione; intelligibli autem luminis datione ipsius, impassibili et immateriali mente participantes et super mentem unitione, in ignotis et beatis immissionibus superclarorum radiorum, in diviniore imitatione supercaelestium mentium. Nam aequales erimus angelis, ut veritas dicit Eloquiorum, et filii Dei, resurrectionis filii existentes.

89 Expositio 210C, p. 249, l. 102-103.

9o Chlup 2012, p. 99-105. 
cycle, as well as a semi-permanent "pneumatic" body which accrues to the first body in its descent, which survives bodily death and is subject to divine reprobation or reward between reincarnations. ${ }^{91}$ This pneumatic vehicle, in turn, is what pervades the corruptible body. Reading only the Elements of Theology, though it presents a view consonant with that commentary, one could be forgiven for not discerning this threefold distinction, but instead only a twofold distinction between the soul's permanent and accrued bodies, which is perhaps an important factor in Berthold's attempt to harmonise Proclus with the Clavis.

The Clavis presents the spiritual body as one and universal, belonging to the "universal human". ${ }^{92}$ Individual corporeal bodies arise as bundles of accidents in the realm of temporal and spatial division. ${ }^{93}$ These particular bodies are not the natural bodies of their souls but garments "superadded" to common humanity. ${ }^{94}$ In this sense, as John Marenbon notes, there is in Eriugena no concern to explain how substances as such are individuated, since individuals are "concourses of accidents". ${ }^{95}$ For Berthold, citing the Clavis, each human being does not have two bodies, but one by which, connaturally and consubstantially joined to the soul, man is substantially constituted. ${ }^{96}$ The incorruptible body is the only substantial body and is, by this reasoning, wholly unitary. ${ }^{97}$

This ontology has a direct relation to Eriugena's doctrine of the general Resurrection, according to which the diversity of fallen humanity will be restored to itself as it has always existed substantially in the divine Word. ${ }^{98}$ Material differentiation falls away entirely. Souls which in Paradise existed in possibility in the universal human will be differentiated only by their merits and virtues (but

91 See Propositions 196 and 207-210 with the comments of E.R. Dodds and Appendix II in Proclus $1963^{2}$, p. $313-321$, with references to the Commentarius in Timaeum. According to Dodds, Proclus is not aiming to address the problem of individuation as such but to harmonise discordant strains of the earlier Platonic tradition. See also Opsomer 20o6, p. 148-151.

92 Eriugena also calls it "the plenitude of humanity" (plenitudo humanitatis), following Gregory of Nyssa: Periphyseon, IV.759AB; V.922A-C, 942B-C, 953A-B, 957C. Cf. Erismann 2011, chapters $3-4$.

93 Expositio 74C, p. 55, l. 206-p. 56, l. 227 = Clavis 411-413 and 416. Cf. Periphyseon, v.941D944B.

94 Expositio 196F = Clavis 272, cf. Periphyseon, IV.801C.

95 Marenbon 2014, p. 362-363.

$96 \quad$ Expositio $210 \mathrm{C}=$ Clavis 273, cf. Periphyseon, IV.803A.

97 Expositio 196F, p. 129, l. 212-214 = Clavis 272: Universaliter autem in omnibus corporibus humanis una eademque forma communis omnium intelligitur et semper in omnibus incommutabiliter constat.

$98 \quad$ Steel 2002. 
not vices) and not by any individual body. ${ }^{99}$ As Tullio Gregory observes, Eriugena overall is less concerned with the status of individual souls than with the unity and future integrity of humanity, ${ }^{100}$ and with situating this general return within the rhythm of nature's return to the primordial causes.

Our commentator evidently finds himself in uncharted territory. Berthold appears slightly uneasy when he first introduces these ideas from the Clavis in 196F. He bookends the long series of citations from the text with two cautionary remarks:

Sane de corpore, quo anima rationalis primo uti dicitur et quod semper animat esse suo, nihil habeo temere definire, cum oporteret esse perpetuum sicut habens subsistentiam ingenerabilem et incorruptibilem et inalterabilem, cum ad instar corporis caelestis impressiones non recipiat, si esse ponitur peregrinas. Audiamus tamen, quid Theodorus in Clave sentiat de hoc corpore $[\ldots]$.

Haec sine praeiudicio sint adducta ad hoc solum, ut clarescat, quid circa praesentem intentionem doctores ecclesiastici senserint. ${ }^{101}$

Berthold, in the first instance, recognises that the force of Proclus's argument requires a very close analogy between the incorruptible status of the body of heavenly souls (see below) and that of human souls, and he hesitates to draw this comparison too rashly. He presents what Theodorus judged (sentiat) about this kind of body (de hoc corpore) in the human. Since he reassures his readers by the end of the discussion that the Clavis presents its doctrine under "the most sound and catholic faith of the divine theologians, Gregory and Maximus," which itself is based on "unshakeable arguments",102 the tone of Berthold's should be understood less as a note of disapproval than an acknowledgment that he has introduced views from the doctors of the church which would be unfamiliar to his audience. This interpretation of his perspective in Proposition $196 \mathrm{~F}$ will conform best to the overall tenor of his later considerations of the issue. After Proposition 196, Berthold will still have to determine the analogy between the permanent bodies of heavenly and human souls.

\footnotetext{
99 Periphyseon, V.983B; 987A-D.

$100 \quad$ Gregory 1977.

101 Expositio 196F, p. 126, 1. 128-131; p. 130, 1. 252-253.

102 Expositio 196F, p. 130, l. 228-231 = Clavis 327 (p. 66, 1. 160-164): Sanissima namque et catholica fide credimus divinorum virorum theologi, videlicet Gregorii et Maximi, de talibus inconcussas rationes reddentium dogmate imbuti, quod Conditor humanae naturae totam simul eam creavit nec animum ante corpus nec corpus ante animam condidit. Cf. Periphyseon, $\mathrm{v} .884 \mathrm{~B}-\mathrm{C}$.
} 
Berthold's presentation of the permanent susceptaculum in the case of heavenly souls, beginning in $196 \mathrm{D}-\mathrm{E}$, takes its principal arguments from Dietrich of Freiberg and Averroes. Unlike incorruptible or heavenly bodies, among corruptible bodies the indeterminate dimensions in matter precede the form, so that the intrinsic principles of a body are not principles as such (they do not exercise intelligible and causal determination), but are first "individual natures" rather than "beings according to species". The situation is otherwise for incorruptible bodies: a heavenly body is first simply "heaven" before it is "this heaven" (hoc caelum); it is by nature intrinsically and fully ordered to its act without any privation. Adopting Dietrich's vocabulary, it is by nature first an ens secundum speciem before it is an individual. ${ }^{103}$ For Dietrich, an ens secundum speciem is a being which proceeds from God according to a specifying reason (ratio specifica) in the divine mind. This ratio is a formal cause, giving it its definitional content, and situating it as a singular entity within the universe as a per se element of its order. ${ }^{104}$ For something to be first an individual ens hoc before it is an ens secundum speciem means that the universality inherent to the species is achieved only through the succession of individuals, whereas an entity such as a separate intelligence that is an ens secundum speciem as such, without ever becoming an ens hoc, is intrinsically complete and intended per se in the order of nature in its singular existence alone. ${ }^{105}$ The heavenly bodies are located at the boundary of these two orders: by a natural, not a temporal order, a heavenly body belongs first to the perse order of things before it is an individual or ens hoc. The heaven only becomes "this" heaven when it acquires parts posterior to the whole (partes posteriores toto) such as quantitative dimensions. ${ }^{106}$

Berthold uses these arguments relative to the bodies of heavenly souls in Proposition 196, and while he hesitates there to apply the reasoning to the

103 Expositio 196D, p. 125, l. 89-p. 126, l. 103. Cf. Dietrich of Freiberg, De corporibus caelestibus, 8.1-2, p. 384, l. 66-8o. Dietrich draws on Averroes, De substantia orbis, c. 1. All citations of Dietrich refer to page and line number of the editions of the Corpus Philosophorum Teutonicorum Medii Aevi.

104 Dietrich of Freiberg, De origine rerum praedicamentalium, 5.17, p. 184, l. 117-p. 185, l.131. Cf. Id., De visione beatifica 1.2.1.1.3, p. 38, l. 42-80; Id., De intellectu et intelligibili, II.33.5, p. 172, l. 22-28; Id., Quaestio utrum substantia spiritualis sit composita ex materia et forma, II.20, p. 333, l. 181-203. See also Suarez-Nani 1998.

105 Cf. Dietrich of Freiberg, De origine rerum praedicamentalium, 3.24, p. 164, l. 182-186: [...] ens ordinabile in genere simpliciter et per se est ens completum secundum speciem; cuius complementi ratio consistit in eo, ut sit ens per se in habendo suam suam formam substantialem ab agente per se in ordine ad finem per se intentum a natura.

106 The most sustained discussion of individuation in Dietrich is De luce et eius origine, 10.113.3, p. 17, l. 79-p. 20, 1. 89. Cf. Expositio 209B, p. 248, 1. 49-65. 
human corpus spirituale, by Proposition 207 the analogy is drawn explicitly. ${ }^{107}$ This coincides with a greater reliance on Dietrich of Freiberg's treatises on the spiritual body and the Resurrection. When the spiritual body is mentioned again, it is placed together with the heavenly bodies in the intermediary region of Dietrich's ontology as a quasi ens secundum speciem:

Ipsum susceptaculum prius est essentia corporis simpliciter quam corporis huiusmodi, et eius forma (scilicet partialis anima) prius unitur essentiae sui susceptibili, ut est essentia corporis simpliciter quam huius corporis. Et per consequens unio animae partialis cum suo susceptaculo praecedit dimensiones, quaecumque sibi fingerentur inexistere, et ex hoc non solum anima partialis, sed etiam ipsius susceptaculum est indivisibile secundum substantiam.

Cum igitur susceptaculum animae partialis, quod primitus animat suo esse et sit immateriale [...] et unio eius cum sua anima praecedat dimensiones - sive dicantur interminatae vel terminatae-, ipsum necessario erit indivisibile secundum substantiam ad instar corporum caelestium, in quibus prius natura unitur anima suo subiecto, inquantum sunt principia seu entia ut simpliciter et constituitur caelum prius natura ut ens simpliciter et quasi ens secundum speciem et deinde determinatur in individuum, ut sit hoc caelum. ${ }^{108}$

How Berthold conceives of this union of the soul with corpus simpliciter prior to hoc corpus, "after the example of the heavenly bodies", is clearest in his comments on the final Proposition of the Elements of Theology, where he undertakes a remarkable synthesis of Dietrich's ontology and the Clavis within a kind of rarified narrative of the soul's descent through the heavens which he finds in Macrobius and Proclus. ${ }^{109}$ It is perhaps no coincidence that Berthold's trepidations in Proposition 196 disappear after his correction of Proclus on metemsomatosis in Proposition 206. ${ }^{110}$ This is perhaps primarily due to his interpreta-

107 Expositio 207F, p. 231, l. 207-213: [...] susceptaculum partialis animae, cum hanc habeat rationem ad susceptaculum divinae animae, quam habet anima partialis ad divinam, sub qua ordinata est secundum substantiam [...].

108 Expositio 208E, p. 236, l. 161-172; p. 237, l. 181-187. Dietrich does not draw the parallel with celestial and human souls as Berthold does. This expansion amounts to making human nature a per se element in the order of the whole.

109 Berthold discusses these narratives of descent at length: Expositio 206D-E, p. 219, l. 115p. 222, 1. 227.

110 Again in Expositio 208E (236,161-172) the same arguments used for heavenly bodies are straightforwardly applied to the human soul's susceptaculum. By Expositio 211D, p. 262, 
tion of the distinction between being and becoming (in ente, in generatione) as it is presented in Proposition 206. Once the condition of the soul in ente is associated with an eternal present, most importantly through the anthropology of the Clavis, Berthold can forge an account of the soul's descent into generation which can be harmonised with Dietrich's ontology of the bodies of heavenly souls.

Berthold begins his comments on Proposition 211 by recalling Proposition 65. The human soul, since it subsists in nature and is not an abstraction, can be considered in three ways (tripliciter considerari): $: 111$ in the nobler mode in which it pre-exists in its cause, in itself according to existence or "essentially", or according to participation, in that the cause is considered in the effect. ${ }^{112}$ The consideration of the human soul secundum causam looks to its subsistence in the hierarchy of primordial causes in light of the plurality of its intrinsic formal principles. But before indicating how one ought to understand this mode of subsistence, Berthold introduces several passages from the Clavis which "alludes" to this Proclean distinction: "The human is a certain intellectual notion eternally made in the divine mind". ${ }^{113}$ However, what he finds in the Clavis is more of a dual than a tripartite consideration - one which, in Proclean terms, centres on the difference between the second and third modes of Proposition 65, in that it explains how the human can be considered (consideratur) either in the Word of God that is the substance of all things or in itself, either in the general primordial causes or in the particular effects, either as eternal or temporal. ${ }^{114}$ As has been stated already, these do not amount to two substances, but to two different reflections (duplex speculatio) on the human substance. For the dual and tripartite structures to align for Berthold, he must frame this constitution of human nature in the Word in terms of the (corrected) Proclean doctrine of the partial soul's descents in relation to being and becoming. ${ }^{115}$

1. 175-177, it is clear that he understands the individuation of the human soul in more Eriugenian terms: Ex quibus aperte colligitur nec substantias seu essentias nec rationes rerum descendere in generationem, sed solum earum passiones seu accidentia. Quid autem veritatis in hoc sit circa animam partialem, plenius elucescet.

111 Expositio 211A, p. 258, 1. 9-10.

112 Expositio, 211A, p. 258, 1.13-31.

113 Expositio, 211A, p. 259, l. 32-51 = Clavis 252 .

114 Expositio, 211A, p. 259, 1. 57-67 = Clavis 254 .

115 However, Berthold presents a kind of threefold consideration of primordial causes, substances and spatio-temporal accidents using a lengthy excerpt from the Clavis that explains how, in Berthold's words, "neither the substances, essence nor reasons of things descend into generation, but only their properties or accidents". See Expositio 211D-E, p. 262, l. 175-p. 263, l. 191, which includes Clavis 330-331 (p. 68, 1. 227-p. 7o, l. 288). 
Berthold ascribes to the Platonists a theory of the twofold descent of the soul: "into being by nature and condition" and "into the particular mode of being related to generation". ${ }^{116}$ But having refuted the literal reading of the soul's descent which would make its pre-existence temporal, Berthold now speaks of this duality, and the internal narrative within each descent, as a reflection only of our mode of thinking (secundum modum nostrum intelligendi). In its first descent, the soul emanates from the Good through the primordial causes into its proper existence. The Good, through the primordial causes, "strengthens the irradiation of itself", so that the first primordial cause, namely primordial Power (prime virtus), bestows by its illumination "the possibility to be", and so on through Being, Life, Intellect and Soul, until finally, "through primordial Nature, it [the human soul] joins to itself a spiritual and connatural body". ${ }^{117}$ This is described as its "singular existence" and condition, not yet having gone forth into individuals. Berthold then gives an extraordinary, but brief, mixture of allusions to the Clavis and Proclus's Tria opuscula: unified with its "concreated natural susceptaculum", the soul in this mode "stands perfectly in the totality and integrity of human nature, in which all humans are-one human formed after the image and likeness of the primal Good". Crucially, Berthold refers to this first descent as the establishment of the human soul "in being", not "in generation", "beyond place and time, where even now it imitates the presiding gods". 118 Thus Berthold combines Proclus and the Clavis by inventing a theory of the twofold descent of the soul: one descent into being, the other into becoming. The first narrates the movement from considering the partial soul secundum causam in the causes to considering it secundum propriam existentiam, and locates the permanent, spiritual body at its final stage. At this stage, the influence of Dietrich of Freiberg can also be detected in Berthold's characterisation of the human nature constituted in the Word as a "singular

116 Expositio 211C, p. 26o, 1. 91-93.

117 Expositio 211C, p. 26o, 1. 101-p. 261, 1. 106: Deinde secundum modum nostrum intelligendi ipsum prime bonum per donationem primordialium causarum fortificat sui ipsius irradiationem [...], per prime naturam coaptat sibi corpus spirituale et connaturale.

118 Expositio 211C, p. 26o, l. 109-p. 261, l. 115: Sic ergo descendens anima per primordiales causas procedit per omnes per se perfectos ordines ipsarum primordialium causarum, ubi semper, plus et plus praemissis donationibus, contrahitur ad animealitatis existentiam singularem et ad unionem sui cum sibi concreato susceptaculo naturali, ubi perfecte stat in humanae naturae totalitate et integritate, in qua sunt omnes homines, unus homo formatus ad imaginem et similitudinem prime boni. Et sic in ente supra loca et tempora collocatur, ubi etiam deos praesides imitatur. This last phrase is Proclean and Berthold employs it relative to the Platonists generally (Proclus, Dionysius, Macrobius, Boethius); see Expositio 206C-D, l. 81-82, 92, 117, 141; 207A, p. 225, l. 18-21; 207B, p. 226, l. 63-p. 227, l. 7 O. 
existence". At last, the analogy between heavenly and human souls is preserved. Berthold has shown that there is a fundamental consensus of the Christian and pagan Platonists even on this difficult doctrine. Just as with the question of the gods in the Elementatio, this reconciliation would have been impossible without Eriugenism. As Dietrich's metaphysics of essential causality is extended and modified in that synthesis of Proclus and Dionysius through Eriugena, so his ontology of heavenly bodies is applied in an entirely new domain to the state of human nature in ente.

There are two further issues where Dietrich is taken up and transformed in Berthold's exposition of Platonic anthropology: first, regarding the characterisation of the spiritual body itself; and second, in describing how the individual, wayfaring soul might be related to the permanent immaterial body.

One can detect intimations of this theory of the first descent and the constitution of the "integrity of human nature" when Berthold uses concepts from Dietrich to describe the nature of the spiritual body constituted spiritually in ente, as distinct from its material state in generatione:

Spiritualitas enim talis aut est contracta per naturam, ex origine scilicet essentiali talis substantiae, et sic susceptaculum, quo primitus utitur anima partialis et quod ipso esse animat, licet sit corpus per essentiam, est spirituale, et hoc spiritualitate, secundum quam abstrahit ab omni loco et situ corporali, contracta per naturam ex origine sua essentiali, secundum quam dependet causaliter ab immobili causa. ${ }^{119}$

For Dietrich, "spirituality contracted by nature", when taken in its essential rather than accidental signification, applies principally to intrinsically spiritual living substances (angels, souls) and equivocally to inanimate spiritual things (spiritual places such as heaven and limbo). ${ }^{120}$ In the passage used by Berthold, Dietrich does not mention any innate spiritualitas belonging to the paradisal body. In the case of the resurrected body, that spiritualitas is only quasi ab extrinsecus indita, and thus the spirituality of souls and resurrected bodies differ "equivocally". ${ }^{121}$ Whereas certain beings are in their proper place by essence (God, the intelligences posited by the philosophers and, perhaps, heavenly souls, since these are all essential causes), certain kinds of spiritual

119 Expositio 208A, p. 232, l. 21-25; cf. Dietrich of Freiberg, De substantiis spiritualibus et corporibus futurae resurrectionis $36.8, \mathrm{p}$. 339, l. 34-40.

120 Dietrich of Freiberg, De substantiis spiritualibus et corporibus futurae resurrectionis 36.4, p. $339,1.15^{-22}$.

121 Dietrich of Freiberg, De substantiis spiritualibus, 36.8, p. 339, l. 34-40. 
substance (angels and human souls) are in their proper place only incohative by essence and completive or destitutive, depending on their merits, by accident. ${ }^{122}$ Thus, in this passage from 208A, Berthold innovates by extending the concept of innate spiritualitas to the susceptaculum, and by adding an allusion to Proposition 207 ( ab immobilicausa), such that the susceptaculum itself possesses spiritual properties by nature, by virtue of its origin from an immobile cause in ente.

A key feature of Eriugena's doctrine is that the substantial spiritual body is a present condition that is "hidden" until the Resurrection. ${ }^{123}$ There is the coincidence of the eternal perspective of God, where human nature subsists, and the accidental, divided condition of material being - again, the substance of the human is one, but is understood in two ways. ${ }^{124}$ Berthold must relate the spiritual and corporeal bodies when commenting on Propositions 209210, where Proclus states that the susceptaculum acquires ever more materiality in its descent, and that it remains self-identical even after the descent. Since spirituality and corporeality are not of the same genus, a spiritual substance can "assume" or "be clothed" with corporeality without leaving off its inherent spirituality. ${ }^{125}$ The subtlety and omnipresence of the invisible elements that underlie and constitute the elements of sense-experience is taken from the Clavis as a sign of, but not equivalent to, the intrinsic subtlety of the spiritual body. ${ }^{126}$ Therefore, although Berthold rejects the descent of souls using Theodorus on the eschatological return of all things into their eternal reasons,

122 Dietrich of Freiberg, De substantiis spiritualibus, 23.1-7, p. 320, l. 41-p. 321, l. 94.

123 Expositio 196F, p. 128, 1. 190-194 = Clavis 105: Cum incorruptibile perire non possit, ubi est nunc corpus incorruptibile, quod animae adhaereret, si non peccaret? Magister: In secretis naturae sinibus adhuc latet; in futuro autem saeculo apparebit, quando mortale hoc in illud mutabitur et corruptibile hoc induet incorruptionem. Cf. Expositio 210c, p. 250, l. 110-114; 210D, p. 243, l. 116-120: [...] ipsum susceptaculum, quo primitus utitur et quod ipso esse suo animat utpote sibi inseparabiliter unitum [...]. Also, Expositio 210M, p. 255, l. 316-320 = Clavis 246: Humana enim natura [...] non est secundum hoc consideranda, quod corporeis sensibus apparet irrationalibus animantibus similis, sed secundum hoc, quod ad imaginem Dei condita est, priusquam peccaret. In hac omne, quod Conditor primordialiter creavit, totum integrum manet. Adhuc tamen latet revelationem filiorum Dei expectans.

124 Expositio 211A, p. 259, l. 66-p. 26o, l. 74 = Clavis 254. Cf. Beierwaltes 1994, p. 82-114.

125 Expositio 209C, p. 242, l. 91-p. 243, l. 110; cf. Dietrich of Freiberg, De substantiis spiritualibus et corporibus futurae resurrectionis 37.8. Using an earlier passage, in which Dietrich explains how two glorified bodies can be in the same place, Berthold argues how spiritual bodies can be in the same place as corporeal bodies, and so combines the argument with Dietrich's next point about the appearance of Christ to Thomas and the other disciples after the Resurrection; cf. Expositio 209A-B, p. 241, 1. 37, 44, 6o-69 and Dietrich of Freiberg, De substantiis spiritualibus et corporibus futurae resurrectionis 31.3-4, 36.9 and 37.7 .

126 Expositio 210A, p. 247, l. 25-p. 248, 1. 47. 
beyond time and place, and nature is transcended because nature no longer appears, he never criticises Proclus relative to the substantial endurance of the spiritual body.

The descent of the soul from being into becoming as outlined in Proposition 211 brings us to the second area of Berthold's transformation of Dietrich's thought in the context of Eriugenian exemplarism. The second descent occurs when it is well-pleasing to the primal Good with the advice of its council (ad beneplacitum prime boni de consilio sui senatus), when "within human nature it is determined to this singular unity, which deiform unity is specified in intellectuality, and this intellectuality is singularised to the existence of this soul, which finally is particularised by the sensible and vegetative [powers]". ${ }^{27}$ Then soul receives a material body, which it uses according to the natural necessities of this mode of being. Berthold holds that the soul is the "mover" rather than the "act" or "form" of the body, which relates to his defense of the doctrine of recollection. ${ }^{128}$ That human nature is in the Word and "even now imitates the presiding gods" is one way of saying that there is a latent, ongoing contemplation of God in the ground of the soul. This connection is drawn explicitly in Proposition 207, on the origin of the susceptaculum from an immobile cause. ${ }^{129}$

These remarks should be interpreted in light of Berthold's comments on Propositions 188 and 193, which provide an equivalent in the Elementatio to Dietrich's theory of the intellect as the essential principle of the soul, and which are in the background to $211 \mathrm{E}-\mathrm{F} .{ }^{130}$ The partial soul passes from intellection to non-intellection. But in every nature whose activity is manifold and imperfect, there must be some recourse to some single, first causal agent. For the soul which sometimes lives according to intellect, therefore, this principle must be

127 Expositio 211C, p. 261, 1.117-124: Existens vero in ente et totalitate naturae humanae, ut dictum est, ad beneplacitum prime boni de consilio sui senatus per descensum secundum (scilicet in generationem) in hunc mundum destinatur, in quo descensu determinatur intra ipsam humanam naturam ad hanc singularem unitatem, quae unitas deiformis specificatur in intellectualitatem et hoc intellectualitas singularizatur in hanc existentiam huius animae, quae etiam ultimo particulatur per sensuale et germinale. Et sic induit corpus materiale, quo etiam utitur secundum talis modi essendi exigentiam naturalem. Cf. Expositio 24B, p. 130, l. $189-198$.

128 Expositio 207C, p. 227, l. 78-p. 228, l. 129. Against the Peripatetics, for Berthold, the Platonists hold that the soul descends "by the will of God" (nutu Dei) into "an arranged body", that it does not "beg" for its intelligible species, but knows by recollecting its vision during its "natural state". For Dietrich's arguments for recollection, see De cognitione entium separatorum 94.6, p. 258, l. 35-42.

129 E.g., Expositio 207A, p. 225, l. 19-21.

130 See Dietrich of Freiberg, De intellectu et intelligibili II.1-12, p. 146, l. 5-p. 155, l. 81. 
incessantly active and intellectual. ${ }^{131}$ Berthold allows for some latitude when naming this principle. Aristotle called it the "agent intellect", Augustine the abditum mentis (Dietrich had accepted these alternatives), Dionysius the "unity exceeding the nature of the mind", and Proclus the "one of the soul" or the "trace of the One". 132 This extends the equivalence between Aristotle and Augustine maintained by Dietrich, though Berthold clearly prefers the Proclean and Dionysian expressions in terms of a unity beyond the intellect, as is clear, for example, when he states that the individual in its second descent is related to the integrity of human nature through the unum animae. Berthold also adopts Dietrich's notion of an inwardness (intraneitas) by which soul cannot be said to be joined to the body as a form, ${ }^{133}$ where the soul is in a mutual and immediate relation to this grounding principle in its essence, such that "one is in the other" in "substantial identity". 134 Building on Dietrich's own recourse to Proclus on the three modes of subsistence (cause-essence-participation) for his theory of the agent intellect as the essential principle of the soul, ${ }^{135}$ Berthold develops an adverbial distinction to explain that the whole (tota) soul remains in its primordial causes, proceeds to its proper existence (the first descent) and even into generation. However, it does not descend into generation according to every mode (totaliter), since it remains in being (in ente), which is the state of its first descent, according to its intellectual being. ${ }^{136}$

For most of its wayfaring life, the soul relates to this inward principle as the ground and efficient cause of its being, not as its form, "although suddenly [raptim] and by a certain crossing-over [transitum] this happens to some".137 This rapture belongs to the accidental rather than natural and essential order, though one can say that it amounts to the realisation of the condition that always belongs to the soul. ${ }^{138}$ For Dietrich, the beatific vision occurs through

\footnotetext{
131 Expositio 211E, p. 263, l. 199-218.

132 Expositio 188E, p. 65, l. 203-232; 193E, p. 103, l. 111-201.

133 Expositio 2118, p. 260, 1. 84-89; cf. Dietrich of Freiberg, De intellectu et intelligibili II.7.3, p. $151,1.56-65$.

134 Expositio 188E, p. 65, l. 213-218; 193E, p. 104, l. 161-164.

135 Dietrich of Freiberg, De intellectu et intelligibili II.1.2, p. 146, l. 13-22.

136 Expositio 211E, p. 263, l. 192-198: Et sic omnis anima partialis per essentiam et se tota manet in suis primordialibus causis et tota procedit seu descendit non solum in suam propriam existentiam, sed etiam in generationem. Sed non totaliter, quia non secundum omnem modum, quo est in suis primordialibus causis quoad primum descensum, nec secundum omnem modem, quo est in ente, quamvis nihil pertinens ad ipsius talis animae substantiam, prout descendit in generationem, maneat in ente quoad secundum descensum sive in esse intellectuali.

137 Expositio 211E, p. 263, 1. 212-216.

138 Expositio 211F, p. 264, l. 246-248: Quamvis enim aliquid eius semper stet in lumine actualis
} 
the soul's formal union with the agent intellect in the ground of the soul through grace. From him Berthold derives the notion that, once united with their own ground, the blessed see God, for they enjoy the direct cognition of God which has always been theirs in the ground. ${ }^{139}$ The content of this union is the cognition of the universe of beings, as Dietrich writes, who gives the example of St. Benedict's rapture as reported by St. Gregory the Great. ${ }^{140}$ Going beyond Dietrich, however, because he has sought a logic that can apply to participable souls, both "partial" and "total", Berthold must admit that the souls animating the heavens permanently enjoy the vision to which the blessed are restored by grace. ${ }^{141}$ For souls to delight in this contemplation not only by transitory rapture but continually, they must have bodies proportionate to that activity. In Proposition 207, which states that the incorruptible susceptaculum must arise from an immobile cause, it is this noetic exigency that guides the discussion of that body's gifts and properties (clarity, subtlety, agility) which he takes from Dietrich. But, as has been noted, whereas Dietrich applies these attributes only to the resurrected body, Berthold applies these attributes to the condition of human nature in its first descent in ente. ${ }^{142}$ However, there are passages which suggest that, although Berthold blurred the boundaries between human and heavenly souls when accounting for the pristine and abiding condition of human nature with the spiritual body in ente, nevertheless he maintained that the highest beatitude of the soul consists not only in being illumined by contemplation and in delight in the fount of all good, but even in being "over-filled" with the clarity of divine light such that the body is glorified through the soul. ${ }^{143}$

Berthold's endorsement of something like an Eriugenian distinction of the general and special return of humanity can be discerned in his discussion of deification as occurring analogously in the microcosm and the macrocosm: all

intelligentiae intelligendo se ipsum et suum principium, a quo intellectualiter et cognitive emanat, tamen ista cognitio non est totius animae nisi per accidens. Cf. Imbach 1978, p. 436.

139 E.g., Expositio 202F, p. 187, l. 217-p. 188, l. 231.

140 Dietrich of Freiberg, De visione beatifica 1.1.4, 5, p. 29, 1. 27-32: Et ex hoc arguit Commentator Super III De anima, quod, si intellectus agens qui est intellectus per essentiam et semper in actu, aliquando uniatur nobis ut forma, per ipsum intelligemus omnia entia. Quod videtur aliqualiter concordare cum eo, quod legitur de sancto Benedicto, videlicet quod in quadam mentis elevatione vidit totum universum.

141 Expositio 202F, p. 188, 1. 231-233: Tali autem unione non carent intellectuales animae, verum semper habent eam dono prime Dei. Cf. Expositio $185 \mathrm{G}-\mathrm{M}$, p. 24, l. 329-p. 28, l. 471.

142 In 207B, Berthold uses texts from Dietrich on the Resurrection to characterise the natural state of the susceptaculum. Cf. Dietrich of Freiberg, De dotibus corporum gloriosorum 4-5, p. 272 , l. 3-p. 273 , l. 36.

143 Expositio 209A, p. 240, l. 21-31. 
levels of being are preserved but are transformed such that God alone appears in them. ${ }^{144}$ At the Resurrection, the spiritual body will have further gifts "from without" according to the order of voluntary providence (merit and punishment), in addition to its inherent spiritual qualities. ${ }^{145}$ Thus the return to the integrity of human nature in ente would correspond to the universal, general return of creation into the primordial causes:

Qualis autem et quanta sit qualitas spiritualis corporis, ut sua unione ad animam non impediat etiam gloriam beatitudinis ipsius sic edisserit Theodorus in Clave: "Quantum ergo sensus noster capere potest qualitatem spiritualis corporis talem quandam esse sentimus, in quo inhabitare deceat non solum sanctas quasque perfectas animas, verum etiam omnem creaturam, quae liberabitur a servitute corruptionis. De quo corpore etiam illud Apostoli dixit: 'Domum habemus non manufactam aeternam in caelis', id est mansionibus beatorum."146

Whatever the diversity of spiritual bodies, one will not exclude the other, for place and time will have perished into the primordial causes. ${ }^{147}$ Even now the first signs are already present, as the invisible yet material "universal" elements permeate all visible bodies. ${ }^{148}$ These phenomena point to the Resurrection from within the natural order. ${ }^{149}$ The precise relation between the natural and voluntary order which completes and consummates it, as we have seen, is only hinted at in the Expositio which, according to Berthold, treats only the natural order of providence.

\section{Conclusion}

Berthold's extensive reception of Eriugenism, principally through the Clavis and also through the De causis primis et secundis, the scholia to Dionysius

\footnotetext{
144 Expositio 129B, p. 177, l. 142-p. 178, l. 154, p. 179, l. 198-211, using Clavis 313-314.

145 Expositio 208A, p. 232, l. 26-28, cf. Dietrich of Freiberg, De substantiis spiritualibus et corporibus futurae resurrectionis 36.8 , p. 339, l. $36-39$.

146 Expositio 210c, p. 249, l. 83-91, citing Clavis 398 (p. 13o, l. 2211-2217).

147 Expositio 209A, p. 240, l. 32-p. 241, l. 43, cf. Dietrich of Freiberg, De substantiis spiritualibus et corporibus futurae resurrectionis 31.3, p. 333, l. 52-58; 209F, p. 245, l. 187-200 = Clavis 47 .

148 E.g., Expositio 210A, 129A.

149 Eriugena admits his difficulties in determining whether the general Resurrection is a natural or gracious event (Periphyseon v.898D-906C). He concludes that the Resurrection is natural, but deification is gracious (v.979B-C).
} 
and the Homily, makes the Expositio by far the most extensive documented reception of Eriugenian thought in the Middle Ages. Berthold's doxographical outlook is developed fundamentally under the guidance of a contingent set of manuscripts and misattributions. Nevertheless, the doctrines presented in these texts have a reciprocal relation to the authority granted to them. His project, which places Proclus, Dionysius and the doctors of the church in a broad consensus of Platonism, would have been impossible without Eriugenism. This has been shown concerning his doctrines of first and last things: by Ezequiel Ludueña concerning the gods or primordial causes and now relative to the susceptaculum - two of the most characteristic Proclean doctrines that are excised, as far as possible, in the Liber de causis, which Berthold must confront de novo without the assistance of an earlier interpretative tradition and which, equally, are the aspects of the Elementatio theologica which are perhaps most challenging for Proclus's Christian readers. ${ }^{150}$ The Platonism that Berthold seeks to retrieve and reconstitute through compilation, synthesis and conjecture produces a result that is reducible neither to Eriugena nor, evidently, to Proclus. It is a Platonic philosophy of Christianity which understands itself to be the elucidation of the ancient Platonic wisdom that unites St. Paul, Dionysius and Proclus.

The work of Dietrich of Freiberg is a constant companion to Berthold's project, and his influence is equally important for elucidating both Eriugenian doctrines of the gods or primordial causes and of the spiritual body. One might say that, were it not for his apparently profound formation in Dietrich's way of thinking and thorough familiarity his master's entire oeuvre, Berthold would not have been prepared to see the connections between these texts. It would then be fair to say that, in extending Dietrich's principles both upward (from the intelligences to the gods), downward (to the incorruptible spiritual body), when commenting on Proclus's propositions, Berthold is simply Platonising his master or, in other words, finding a logic more appropriate to certain of Dietrich's aims at the expense of others. Further research may reveal the full extent of his debt to Dietrich, as well as illustrate the cultural context for this resurgence of Eriugenian exemplarism and the return to a golden age of Platonism, decidedly with the Elementatio theologica rather than the Liber de causis, in the Dominican schools of the 14th century. ${ }^{151}$

150 As Trouillard (1973, p. 98) observes of Eriugena's reconstitution of pagan Neoplatonism: "Quand on a le bonheur de lire Jean Scot Érigène, on est surpris de découvrir [...] une telle puissance de pensée et d'expression. Celle-ci lui de réinventer, à travers des documents mineurs, plusieurs des intuitions les plus originales du néoplatonisme".

$15^{1}$ These questions, and a more complete contextualisation of Berthold's Eriugenism, are 


\section{Bibliography}

\section{Manuscripts}

Paris, Bibliothèque nationale de France, lat. 6734

Paris, Bibliothèque nationale de France, lat. 17341

\section{Primary Sources}

Albert the Great, Commentarii in libros Sententiarum, A. Borgnet (ed.), Opera omnia XXV-XXX, Paris, 1893-1894.

Albert the Great, Summa theologiae, A. Borgnet (ed.), Opera omnia XXXI-XXXIII, Paris, 1895 .

Albert the Great, Super Dionysium De divinis nominibus, P. Simon(ed.), editio Coloniensis XXXVII/1, Münster, Aschendorff, 1972.

Albert the Great, Super Mysticam theologiam et Epistulas, P. Simon (ed.), editio Coloniensis XXXVII/2, Münster, Aschendorff, 1978.

Albert the Great, Summa theologiae sive de mirabili scientia Dei, libri I, pars I, quaestiones 1-50A, D. Siedler (ed.), editio Coloniensis Xxxıv/1, Münster, Aschendorff, 1978.

Berthold von Moosburg, Expositio super Elementationem theologicam Procli. De animabus. Propositiones 184-211, L. Sturlese (ed.), Rome, Edizioni di storia e letteratura, 1974.

Berthold von Moosburg, Expositio super Elementationem theologicam Procli. Propositiones 1-13, L. Sturlese, M.-R. Pagnoni-Sturlese (eds), Hamburg, Felix Meiner, 1984.

Berthold von Moosburg, Expositio super Elementationem theologicam Procli. Propositiones 14-34, L. Sturlese, M.-R. Pagnoni-Sturlese, B. Mojsisch (eds), Hamburg, Felix Meiner, 1986.

Berthold von Moosburg, Expositio super Elementationem theologicam Procli. Propositiones 35-65, A. Sannino (ed.), Hamburg, Felix Meiner, 2001.

Berthold von Moosburg, Expositio super Elementationem theologicam Procli. Propositiones 66-107, I. Zavattero (ed.), Hamburg, Felix Meiner, 2003.

Berthold von Moosburg, Expositio super Elementationem theologicam Procli. Propositiones 108-135, F. Retucci (ed.), Hamburg, Felix Meiner, 2011.

Berthold von Moosburg, Expositio super Elementationem theologicam Procli. Propositiones 136-159, F. Retucci (ed.), Hamburg, Felix Meiner, 2007.

Berthold von Moosburg, Expositio super Elementationem theologicam Procli. Propositiones 160-183, U.R. Jeck, I. Tautz (eds), Hamburg, Felix Meiner, 2003.

developed in a forthcoming monograph on Berthold of Moosburg. An earlier version of this paper was presented at the first Colloquium on the Elementatio theologica and Liber de causis in Paris, 14 November 2015. I am very grateful to the participants in this session for their comments, and in particular to Dragos Calma. 
Berthold von Moosburg, Expositio super Elementationem theologicam Procli. Propositiones 184-211, L. Sturlese, A. Punzi (eds), Hamburg, Felix Meiner, 2014.

Dietrich von Freiberg, Opera omnia, t. I: Schriften zur Intellekttheorie, B. Mojsisch (ed.), Hamburg, Felix Meiner, 1977.

Dietrich von Freiberg, Opera omnia, t. II: Schriften zur Metaphysik und Theologie, R. Imbach, M.R. Pagnoni-Sturlese, H. Steffan, L. Sturlese (eds), Hamburg, Felix Meiner, 198o.

Dietrich von Freiberg, Opera omnia, t. III: Schriften zur Naturphilosophie und Metaphysik, J.-D. Cavigioli, R. Imbach, B. Mojsisch, M.-R. Pagnoni-Sturlese, R. Rehn, L. Sturlese (eds), Hamburg, Felix Meiner, 1983.

Dietrich von Freiberg, Opera omnia, t. IV: Schriften zur Naturwissenschaft, Briefe, M.R. Pagnoni-Sturlese, R. Rehn, L. Sturlese, W. Wallace (eds), Hamburg, Felix Meiner, 1985 .

Dionysius ps.-Areopagita, Dionysiaca, Ph. Chevallier (ed.), Bruges, Desclée de Brouwer, 1937-1950.

Honorius Augustodunensis, Clavis physicae, P. Lucentini (ed.), Rome, Edizioni di storia e letteratura, 1974.

Honorius Augustodunensis, La Clavis physicae (316-529) di Honorius Augustodunensis, P. Arfé (ed.) Naples, Liguori Editore, 2012.

John Scotus Eriugena, L'Homélie sur le prologue de Jean, E. Jeauneau (ed.), Paris, Cerf, 1969 .

John Scotus Eriugena, Periphyseon, E. Jeauneau (ed.), Turnhout, Brepols, 1996-2002.

Liber de causis - A. Pattin, "Le Liber de causis. Édition établie à l' aide de 90 manuscrits avec introduction et notes", in Tijdschrift voor Filosofie 28 (1966), p. 90-203.

Proclus, Tria opuscula:De providentia, libertate, malo, interprete Guillelmo de Moerbecca, H. Boese (ed.), Berlin, De Gruyter, 196o.

Proclus, The Elements of Theology, E.R. Dodds (ed.), Oxford, Clarendon Press, 1963; Proclus, Elementatio theologica, translata a Guillelmo de Morbecca, H. Boese (ed.), Leuven, Leuven University Press, 1987.

Proclus, On the Existence of Evils, J. Opsomer, C. Steel (trans.), Ithaca, Cornell University Press, 2003.

Thomas Aquinas, Scriptum super libros Sententiarum, vol. 3, M.F. Moos (ed.), Paris, P. Lethielleux, 1927.

Thomas Gallus, Explanatio in libros Dionysii, D. Lawell (ed.), Turnhout, Brepols, 2011.

Ulrich von Strassburg, De summo bono, liber II, tractatus 1-4, A. de Libera (ed.), Hamburg, Felix Meiner, 1987.

Ulrich von Strassburg, De summo bono, liber II, tractatus 5-6, A. Beccarisi (ed.), Hamburg, Felix Meiner, 2007. 


\section{Secondary Sources}

Allen, P., B. Neil (eds) (2002), Maximus Confessor and his Companions:Documents from Exile, Oxford, Oxford University Press.

Beierwaltes, W. (ed.) (1987), Eriugena redivivus. Zur Wirkungsgeschichte seines Denkens im Mittelalter und im Übergang zur Neuzeit. Vorträge des V. Internationalen EriugenaColloquiums, Werner-Reimers-Stiftung, Bad Homburg, 26.-3o. August 1985, Heidelberg, Carl Winter.

Beierwaltes, W.(1994), Eriugena: Grundzüge seines Denkens, Frankfurt am Main, V. Klostermann.

Chlup, R. (2012), Proclus: an Introduction, Cambridge, Cambridge University Press.

Crouse, R. (2002), "Predestination, Human Freedom and the Augustinian Theology of History in Eriugena's De divina praedestinatione", McEvoy, Dunne 2002, p. 3033011.

D’Alverny, M.-Th. (1953), "Le cosmos symbolique du XII siècle", in Archives d'histoire doctrinale et littéraire du Moyen Age 20, p. 31-81

D’Alverny, M.-Th. (1973), "Une rencontre symbolique de Jean Scot Érigène et d'Avicenne. Notes sur le De causis primis et secundis et fluxu qui consequitur eas", in O'Meara, Bieler 1973, p. 170-181.

D’Alverny, M.-Th. (1993), Études sur le symbolisme de la Sagesse et sur l'iconographie, C. Burnett (ed.), Aldershot, Variorum.

De Vaux, R. (1934), Notes et textes sur l'avicennisme latin aux confins des XII ${ }^{e}-X_{I I}{ }^{e}$ siècles, Paris, Vrin.

Dondaine, H.-F. (1953), Le Corpus dionysien de l'université de Paris auXIII siècle, Rome, Edizioni di storia e letteratura.

Erismann, Ch. (2002), "Causa essentialis. De la cause comme principe dans la métaphysique de Jean Scot Érigène”, in Quaestio 2, p. 187-215.

Erismann, Ch. (2011), L'Homme commun. La genèse du réalisme ontologique durant le haut Moyen Âge, Paris, Vrin.

Gersh, S. (2001), "Berthold of Moosburg and the Content and Method of Platonic Philosophy”, J. Aertsen, K. Emery, Jr., A. Speer (eds), Nach der Verurteilung von 1277: Philosophie und Theologie an der Universität von Paris im letzten Viertel des 13. Jahrhunderts, Berlin, De Gruyter, p. 493-503.

Gregory, T. (1977), "L'eschatologie de Jean Scot", in R. Roques (ed.), Jean Scot Érigène et l'histoire de la philosophie: Laon 7-12 juillet 1975, Paris, Centre national de la recherche scientifique, p. 377-392.

Imbach, R. (1978), "Le néoplatonisme médiéval, Proclus latin et l'école dominicaine allemande", in Revue de Théologie et de Philosophie 110, p. 427-448.

Jeauneau, E. (1987), Études érigéniennes, Paris, Études augustiniennes.

Lehmann, P. (1917), "Zur Kenntnis und Geschichte einiger Johannes Scottus zugeschriebener Werke", in Hermes: Zeitschrift für klassische Philologie 52, p. 112-124. 
Lucentini, P. (1980), Platonismo medievale: contributi per la storia dell'eriugenismo, Florence, La Nuova Italia.

Lucentini, P. (2007), Platonismo, ermetismo, eresia nel medioevo, Louvain-la-Neuve, Brepols.

Ludueña, E. (2010), "Nicolás de Cusa: una contribución a la historia del eriugenismo", in J.M. Machetta, C. D’Amico (eds), Nicolás de Cusa, identidad y alteridad: pensamiento y diálogo, Buenos Aires, Biblos, p. 75-88.

Ludueña, E. (2013a), La recepción de Eriúgena en Bertoldo de Moosburg: Un aporte sobre la Escuela de Colonia, Saarbrücken, Publicia.

Ludueña, E. (2013b), "Eriúgena en el siglo XIV: Su presencia en la Expositio de Bertoldo de Moosburg", in Scintilla 10/2, p. 99-154.

Ludueña, E. (2015), “Creatio y determinatio en la Escuela Renana: de Alberto Magno a Bertoldo de Moosburg", in Princípios: Revista de Filosofia, 22/37, p. 77-97.

Mainoldi, E.S. (2005), "Iohannes Scottus Eriugena", in P. Chiesa, L. Castaldi (eds), La trasmissione dei testi latini del Medioevo, Florence, Edizioni del Galluzzo, p. 186264 .

Marenbon, J. (1981), From the Circle of Alcuin to the School of Auxerre: Logic, Theology and Philosophy in the Early Middle Ages, Cambridge, Cambridge University Press.

Marenbon, J. (2014), "Eriugena, Aristotelian Logic and the Creation", in W. Otten, M. Allen (eds), Eriugena and Creation: Proceedings of the Eleventh International Conference on Eriugenian Studies, held in honor of Edouard Jeauneau, Chicago, 912 November 2011, Turnhout, Brepols, p. 349-368.

McEvoy, J. (1987), "Iohannes Scottus Eriugena and Robert Grosseteste: an Ambiguous Influence”, in W. Beierwaltes (ed.), Eriugena redivivus. Zur Wirkungsgeschichte seines Denkens im Mittelalter und im Übergang zur Neuzeit. Vorträge des V. Internationalen Eriugena-Colloquiums, Werner-Reimers-Stiftung, Bad Homburg, 26.-30. August 1985, Heidelberg, Carl Winter, p. 192-223.

McEvoy, J., Dunne, M. (eds) (2002), History and Eschatology in John Scottus Eriugena and his Time: Proceedings of the Tenth International Conference of the Society for the Promotion of Eriugenian Studies, Maynooth and Dublin, August 16-20, 2000, Leuven, Leuven University Press

Opsomer, J. (2006), “Was sind irrationale Seelen?”, in M. Perkams, R.M. Piccione (eds), Proklos: Methode, Seelenlehre, Metaphysik, Leiden, Brill, p. 136-166.

O'Meara, J.J., Bieler, L. (eds) 1973, The Mind of Eriugena, Dublin, Irish University Press for Royal Irish Academy, p. 98-113.

Pagnoni-Sturlese, M.-R. (1984), "Filosofia della natura e filosofia dell'intelletto in Teodorico di Freiberg e Bertoldo di Moosburg", in K. Flasch (ed.), Von Meister Dietrich zu Meister Eckhart, Hamburg, Felix Meiner, p. 115-127.

Pattin, A. (1966) see Liber de causis

Pratsch, Th. (1998), Theodorus Studites (759-826)—zwischen Dogma und Pragma: der 
Abt des Studiosklosters in Konstantinopel im Spannungsfeld von Patriarch, Kaiser und eigenem Anspruch, Frankfurt am Main, P. Lang.

Retucci, F. (2008), “Tommaso di York, Eustrazio e la dottrina delle idee di Platone", in A. Beccarisi, R. Imbach, P. Porro (eds), Per perscrutationem philosophicam: neue Perspektiven der mittelalterlichen Forschung. Loris Sturlese zum 6o. Geburtstag gewidmet, Hamburg, Felix Meiner, p. 79-111.

Retucci, F., J. Goering (2010), "The Sapientiale of Thomas of York, of M: the Fortunes and Misfortunes of a Critical Edition", in Bulletin de philosophie médiévale 52, p. 133-155.

Steel, C. (2002), "The Return of the Body into Soul: Philosophical Musings on the Resurrection", in J. McEvoy, M. Dunne (eds), History and Eschatology in John Scottus Eriugena and his Time: Proceedings of the Tenth International Conference of the Society for the Promotion of Eriugenian Studies, Maynooth and Dublin, August 16-20, 2000, Leuven, Leuven University Press, p. 581-6o9.

Sturlese, L. (1985), "Note su Bertoldo di Moosburg O.P., scienziato e filosofo", in Freiburger Zeitschrift für Philosophie und Theologie 32, p. 249-259.

Sturlese, L. (2013), Die Philosophie im Mittelalter: von Boethius bis Cusanus, Munich, C.H. Beck.

Suarez-Nani, T. (1998), “Remarques sur l' identité de l' intellect et l' altérité de l' individu chez Thierry de Freiberg”, in R. Imbach, F. Cheneval (eds), Albert le Grand et sa réception au Moyen Age. Hommage à Zénon Kaluza, Freiburger Zeitschrift für Philosophie und Theologie 45, p. 96-115.

Suchla, B.R. (1980), Die sogennanten Maximus-Scholien des Corpus-Dionysiacum Areopagiticum, Göttingen, Vandenhoeck \& Ruprecht.

Trouillard, J. (1973), "Érigène et la théophanie créatrice”, in O’Meara, Bieler 1973, p. 98113 .

Trouillard, J. (1984), "Métensomatose proclienne et eschatologie érigénienne”, J. Sojscher, G. Hottois (eds), Philosophies non-chrétiennes et christianisme, Annales de l'Institut de Philosophie et de Sciences morales de l'Université Libre de Bruxelles, p. 8799 .

Trouillard, J. (2014), Raison et mystique: Études néoplatoniciennes, M. Goy (ed.), Paris, Cerf. 